\title{
SCIENTIFIC REPORTS

\section{OPEN Bubble-mediated transport of benthic microorganisms into the water column: Identification of methanotrophs and implication of seepage intensity on transport efficiency}

\author{
Sebastian F. A. Jordan ${ }^{1 *}$, Tina Treude ${ }^{2}$, Ira Leifer ${ }^{3}$, René Janßen ${ }^{1}$, Johannes Werner ${ }^{1}$, \\ Heide Schulz-Vogt ${ }^{1} \&$ Oliver Schmale ${ }^{1 *}$
}

Benthic microorganisms transported into the water column potentially influence biogeochemical cycles and the pelagic food web structure. In the present study six gas-releasing vent sites in the Coal Oil Point seep field (California) were investigated, and the dislocation of microorganisms from the sediment into the water column via gas bubbles released from the seabed was documented. It was found that the methanotrophs transport efficiency was dependent on the volumetric gas flow, with the highest transport rate of $22.7 \times 10^{3}$ cells mL ${ }_{\text {gas }}{ }^{-1}$ at a volumetric gas flow of $0.07 \mathrm{~mL}_{\text {gas }} \mathrm{s}^{-1}$, and the lowest rate of $0.2 \times 10^{3}$ cells $\mathrm{mL}_{\text {gas }}{ }^{-1}$ at a gas flow of $2.2 \mathrm{~mL}_{\text {gas }} \mathrm{s}^{-1}$. A simple budget approach showed that this bubble-mediated transport has the potential to maintain a relevant part of the watercolumn methanotrophs in the seep field. The bubble-mediated link between the benthic and pelagic environment was further supported by genetic analyses, indicating a transportation of methanotrophs of the family Methylomonaceae and oil degrading bacteria of the genus Cycloclasticus from the sediment into the water column. These findings demonstrate that the bubble-mediated transport of microorganisms influences the pelagic microbial abundance and community composition at gasreleasing seep sites.

The exchange of nutrients and organic matter between benthic and pelagic compartments affects the composition of the respective microbial communities and thus their functional capabilities in shelf seas. Microorganisms transport to and from the sediment and water column also has been described and occurs by a variety of exchange processes. For example, the suspension of benthic bacteria from beach material within the splash zone can facilitate cell transport into coastal water (over-beach transport) ${ }^{1,2}$. In addition, bacteria located at shallow sediment depths can be mobilized by infiltrating seawater and then carried to deeper sediment strata, from where they can be injected into the water column by submarine groundwater discharge (through-beach transport) ${ }^{3}$. Another bentho-pelagic transport mechanism in shallow waters is sediment resuspension triggered by wind-induced mixing, breaking waves, tides, bioturbation, and gas bubble transport ${ }^{4,5}$. Microorganisms in the sediments usually are associated with fine particles $(<60 \mu \mathrm{m})^{6}$ at concentrations that exceeds those in the water column by up to four orders of magnitude ${ }^{7}$. Resuspension by tidal currents can increase bacteria concentrations especially within the benthic boundary layer, that is thought to be characterized by a distinct microbial community with high activity ${ }^{8-10}$. Together, these exchanges and transport mechanisms may influence the coastal planktonic microbial food web $^{11-13}$ and alter biogeochemical cycles ${ }^{12,14}$.

${ }^{1}$ Leibniz Institute for Baltic Sea Research Warnemünde, Rostock, Germany. ${ }^{2}$ University of California, Los Angeles Department of Earth, Planetary, and Space Sciences, Los Angeles, California, USA. ${ }^{3}$ Bubbleology Research International, Solvang, California, USA. *email: sebastian.jordan@io-warnemuende.de; oliver.schmale@iowarnemuende.de 

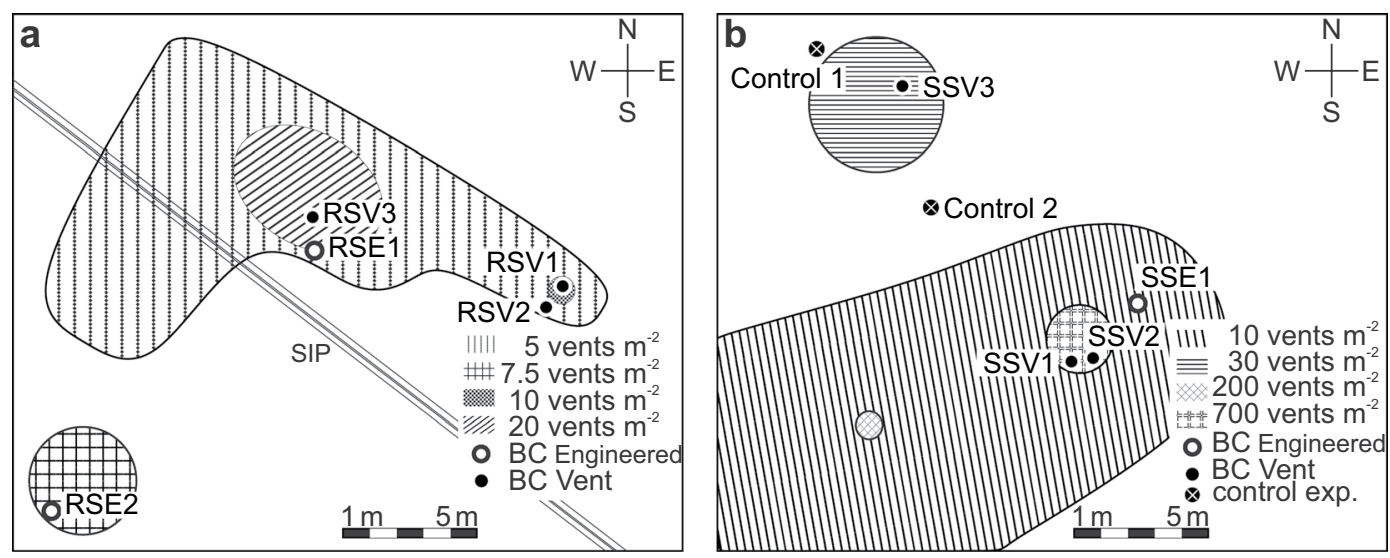

Figure 1. Schematic map of vent distribution and density at (a) Rostocker Seep (RS) and (b) the Isla Vista Super Seep (SS). Locations of the Bubble Catcher (BC) vent, engineered, and control experiments are marked. The double line illustrated in (a) represents the two seawater intake pipes (SIP) that transport seawater from further offshore to the University of California, Santa Barbara campus. CorelDRAW 2018 (v. 20.1.0.708) was used to draw these maps.

Shallow marine areas characterized by methane-containing sediments contribute significantly to atmospheric methane input ${ }^{15,16}$. Here, methane migrates from the seabed into the water column via pore water diffusion, advective fluid flow, and/or bubble ebullition ${ }^{17}$. Such gas bubbles also transfer trace gases (e.g. short-chain hydrocarbons or hydrogen sulfide $)^{18}$ from the sediment to the water column together with mineral particles ${ }^{19}$, organic matter ${ }^{20}$, and microorganisms $s^{7,20}$. Surfactants attached to the bubbles' gas/water interfaces can be released by shear stress, bubble dissolution ${ }^{21}$, or bursting at the sea surface ${ }^{22-24}$. Bubble transport is the most efficient pathway of methane transfer between the sediment and atmosphere and bypasses the very effective anaerobic and aerobic microbial methane oxidation ${ }^{17}$. After methane is released from the sediment, several processes determine the amount that reaches the sea surface, especially water depth ${ }^{18,25}$, ocean currents and mixing ${ }^{26}$, water-column stratification $^{27-30}$, and microbial methane oxidation ${ }^{17,31}$. Microbial methane sink mechanisms reduce the annual seabed methane emissions to the atmosphere from 8-65 $\mathrm{Tg} \mathrm{CH}_{4}{ }^{17}$ to $\sim 1-35 \mathrm{Tg} \mathrm{CH}_{4}$, respectively ${ }^{32}$.

Methane-oxidizing bacteria (MOB) are frequently found in the water column above methane seep sites ${ }^{33-36}$, but how these slow-growing microorganism $\mathrm{s}^{37}$ achieve a significant population density in waters that are renewed continuously by local currents is unclear ${ }^{7,38}$. The findings of previous studies conducted in areas surrounding seep sites $^{7,29,39,40}$ and mud volcanos ${ }^{35}$ suggested that anaerobic methanotrophic archaea and MOB are transported by methane seep bubbles into the water column ${ }^{35,36}$. This hypothesis was based on the higher abundance of MOB in the vicinity of gas bubble flares than in nearby sites not affected by gas bubble emissions from the sediment. In a pilot study at one gas bubble releasing vent site at a shallow nearshore seep field in California, Schmale et al. ${ }^{7}$ found first indications of a direct bentho-pelagic transport of MOB, by sampling escaping bubbles directly at the gas-releasing vent hole. A comparison showed that the natural bubbles released from the sediment transported more MOB cells than the bubbles that were released from an engineered gas outlet above the sediment surface. Although the factors controlling bubble-mediated transport were unknown, Schmale et al. ${ }^{7}$ hypothesized that transported MOB can inoculate overlaying waters, thereby enhancing the efficiency of the pelagic methane sink.

In this detailed mechanistic study, we conducted a series of bubble-catcher experiments at two different seep sites to assess the influence of the parameters seep intensity, bubble size distribution, and vent density on the efficiency of the bubble-mediated transport of benthic microorganism into the water column. Selected genetic community comparisons of sedimentary, pelagic, and transported microorganisms enabled us to further verify the existence of the Bubble Transport Mechanism and to discuss its impact on biogeochemical transformations in the water column. Finally, a simple budget calculation was applied to assess the impact of the Bubble Transport Mechanism on the water column MOB abundance above the Coal Oil Point (COP) seep field.

Results

Distribution of vent sites in the study areas. The vent densities of Rostocker Seep (RS) ranged from 5 to 20 vents $\mathrm{m}^{-2}$, and at IV Super Seep (SS) from 10 to about 700 vents $\mathrm{m}^{-2}$ (Fig. 1). The highest vent density, covering an area of $\sim 16 \mathrm{~m}^{2}$, was at IV Super Seep. Gas bubble emissions generally were more vigorous at IV Super Seep than at Rostocker Seep.

Characterization of sediment and water column. The surface sediments at Rostocker Seep and IV Super Seep generally were dominated by a medium sand fraction but the two seeps differed in that IV Super Seep also was characterized by tar deposits in sediment cores and on the sediment surface. Methane sediment concentrations for both seep sites were in the millimolar range and increased with increasing sediment depth, from $0.05 \mathrm{mmol} \mathrm{L}^{-1}$ at the sediment surface $(0-1.5 \mathrm{~cm}$ b.s.f. $=$ centimeters below the seafloor $)$ to $1.5 \mathrm{mmol} \mathrm{L}^{-1}$ at $10 \mathrm{~cm}$ b.s.f. (Fig. 2 d). Total cell counts were consistent over the entire depth range $\left(\sim 1.5 \times 10^{9} \mathrm{cells} \mathrm{cm}^{-3}\right.$, Supplementary Table S1), although MOB abundances as a percentage of total cell counts decreased from $\sim 7 \%$ at the sediment surface $\left(\sim 8 \times 10^{7}\right.$ cells $\left.\mathrm{cm}^{-3}\right)$ to $\sim 0.5 \%$ at $10.5 \mathrm{~cm}$ depth (Fig. $2 \mathrm{e}$ ). 
a

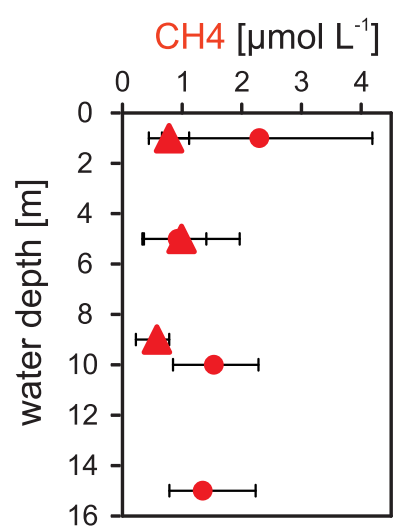

d

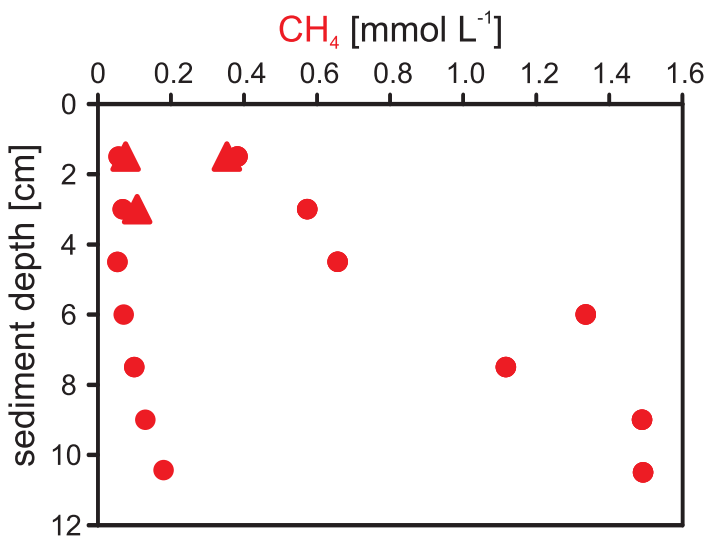

C
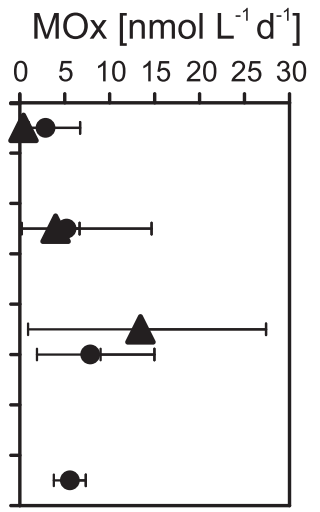

$\mathrm{MOB}$ and total cell count [cells $\mathrm{mL}^{-1}$ ]

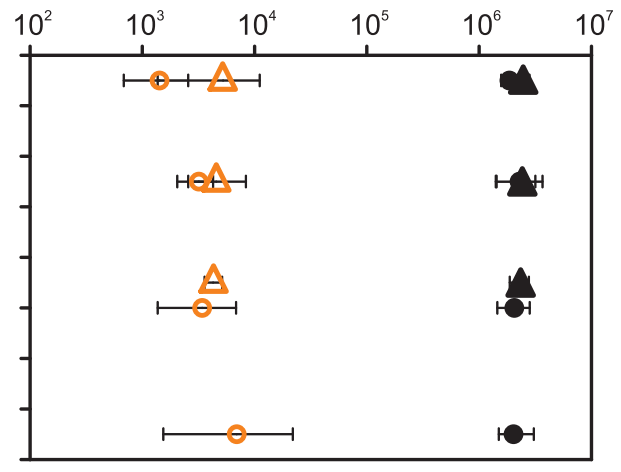

e

\section{$\mathrm{MOB}$ and total cell count [cells $\mathrm{cm}^{-3}$ ]}

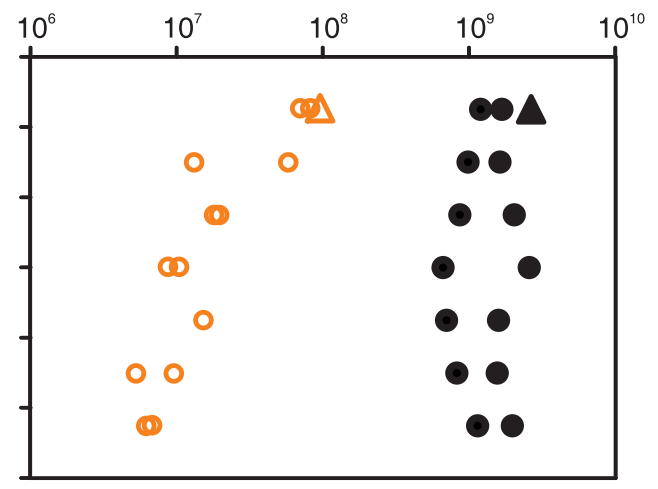

Figure 2. Depth profiles of parameters determined in the water column $(\mathbf{a}-\mathbf{c})$ and in the sediment $(\mathbf{d}, \mathbf{e})$ at the Rostocker Seep (triangle) and the IV Super Seep (circles): (a) mean water column methane concentration, (b) mean water column methane oxidation (MOx), (c) abundance of methane-oxidizing bacteria (MOB, open orange symbols) and total cells (black) in the water column, (d) sediment methane concentration, (e) abundance of MOB (open orange symbols) and total cells (filled black) in the sediment. The bars in (a-c) indicate the range of values between three fieldwork days.

Water column temperature profiles taken over the course of the sampling campaign indicated the buildup of a thermocline over several hours that then collapsed from mixing during the course of the day (data not shown). Throughout the sampling campaign, bottom currents followed the coast, consistent with typical northern Santa Barbara Basin currents, which are driven by the Davidson Current ${ }^{41}$. Water column turbidity changed on a daily basis, resulting in a visibility that ranged from $<0.5 \mathrm{~m}$ up to $10 \mathrm{~m}$ (reported by divers). The water in the vicinity of both seep sites was enriched in methane (Fig. 2a) which varied on a daily basis. Mean methane concentrations were consistently lower at Rostocker Seep than IV Super Seep by a factor of about two throughout the water column. At Rostocker Seep, methane oxidation rates (MOx) increased with increasing water depth, with the highest rate occurring in the bottom waters (min. $0.1 \mathrm{nmol} \mathrm{L}^{-1} \mathrm{~d}^{-1}$ and max. $27.4 \mathrm{nmol} \mathrm{L}^{-1} \mathrm{~d}^{-1}$, (Fig. 2b). By contrast, at IV Super Seep, the highest oxidation rate was measured in intermediate waters (min. $0.7 \mathrm{nmol} \mathrm{L}^{-1} \mathrm{~d}^{-1}, \max .15$ $\mathrm{nmol}^{-1} \mathrm{~d}^{-1}$, (Fig. 2b). Total cell numbers were consistent throughout the water column and seep sites $\left(\sim 2 \times 10^{6}\right.$ cells $\mathrm{mL}^{-1}$, Supplementary Table S2), with MOB abundances of $\sim 4 \times 10^{3}$ cells $\mathrm{mL}^{-1}(0.1-0.2 \%$ of DAPI-stained cells) at both seep sites (Fig. 2c). Total cell numbers were approximately three orders of magnitude lower in the water column than in the sediment, and $\mathrm{MOB}$ abundances approximately four orders of magnitude lower. Cell-specific methane oxidation rates ranged from $7.4 \times 10^{-4} \mathrm{fmol} \mathrm{L}^{-1} \mathrm{~h}^{-1}$ to $1.6 \times 10^{-2} \mathrm{fmol} \mathrm{L}^{-1} \mathrm{~h}^{-1}$.

Bubble size distribution. A Bubble Measuring System (BMS) collected seep bubble videos for the Rostocker Seep and IV Super Seep where the Bubble Catcher samples were taken. Analysis of the bubble size distribution (the number of bubbles per second per radius increment passing through a plane) for a Rostocker Seep vent revealed two emissions modes at $r=1,660$ and 2,750 $\mu \mathrm{m}$ (RSV1, Fig. 3a). This seep was well described by Gaussian functions, i.e., a minor seep with formation not resulting from bubble fragmenta$\operatorname{tion}^{42}$. Emissions were as a bubble pulse of bubbles that lasted $\sim 3.5 \mathrm{~s}$ and comprised 774 bubble images. The volumetric gas flow $(Q)$ was $1.0 \mathrm{~mL}_{\text {gas }} \mathrm{s}^{-1}$ and the bubble surface area flux $(A)$ was $10.9 \mathrm{~cm}^{2} \mathrm{~s}^{-1}$, dominated by the larger mode.

Analysis of 5,236 bubble images from a second, smaller, minor Rostocker Seep vent (RSV2, Fig. 3b) identified a dominant mode at $r=1,505 \mu \mathrm{m}$ and a second much smaller mode at $r=1,710 \mu \mathrm{m}$. Three complete pulses 
a

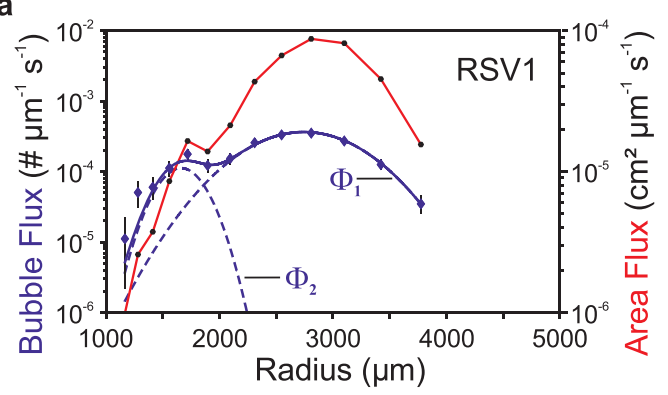

b

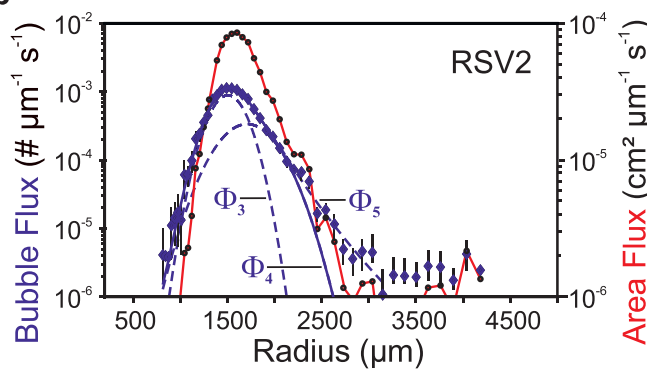

C

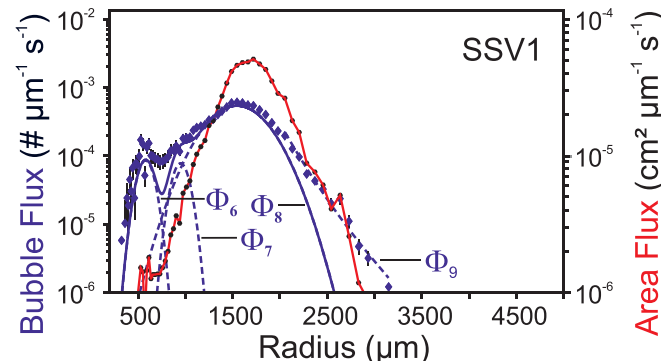

d

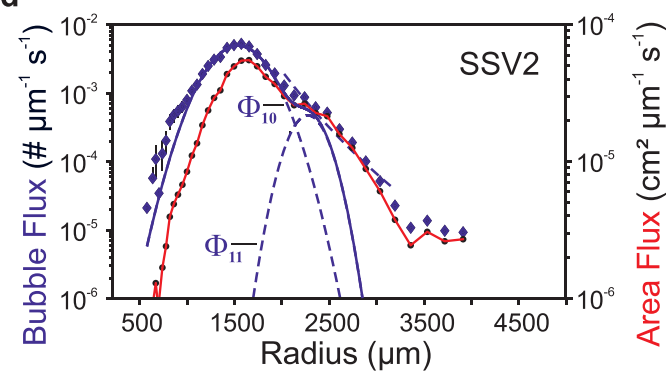

Figure 3. Bubble emission size distribution $(\Phi)$ for bubbles crossing an arbitrary height above the seabed per second per unit radius $(r)$, for the four Bubble Catcher and BMS studied vents: (a,b) Rostocker Seep, (c,d) IV Super Seep. Emission modes determined by least-squares linear-regressions, fit equations $\Phi 1-11$ can be found in the Supplementary Table S3. Also shown is the bubble surface area flux versus $r$.

\begin{tabular}{|c|c|c|c|c|c|c|}
\hline Experiment & Date & \begin{tabular}{|l|} 
Gas volume \\
{$[\mathrm{L}]$}
\end{tabular} & \begin{tabular}{|l|}
$\begin{array}{l}\text { Sampling } \\
\text { duration [min] }\end{array}$ \\
\end{tabular} & $\begin{array}{l}\text { Volumetric flow, } \\
Q\left[\mathrm{~mL}_{\text {gas }} \mathrm{s}^{-1}\right] \\
\end{array}$ & $\begin{array}{l}\text { Transported bubble } \\
\text { surface area, } A\left[\mathrm{~cm}^{2} \mathbf{s}^{-1}\right]\end{array}$ & $\begin{array}{l}\text { Ratio bubble surface to } \\
\text { volume }^{-1}, A / Q\left[\mathrm{~cm}^{-1}\right]\end{array}$ \\
\hline RSV1 & \multirow{2}{*}{01.08 .17} & \begin{tabular}{|l|l}
0.7 \\
\end{tabular} & 160 & 0.07 & 0.8 & 10.5 \\
\hline RSV2 & & 2.85 & 160 & 0.30 & 5.1 & 17.1 \\
\hline RSV3 & \multirow{2}{*}{02.08 .17} & 4.85 & 111 & 0.73 & & \\
\hline RSE1 & & 4.66 & 67 & 1.16 & & \\
\hline RSE2 & 15.08 .17 & 4.7 & 84 & 0.93 & & \\
\hline SSV1 & \multirow{2}{*}{ 07.08.17 } & 5.13 & 50 & 1.71 & 30.9 & 18.1 \\
\hline SSV2 & & 5.42 & 41 & 2.20 & 39.6 & 18.0 \\
\hline SSV3 & 08.08 .17 & 4.7 & 197 & 0.40 & & \\
\hline SSE1 & 14.08 .17 & 5.59 & 9 & 10.35 & & \\
\hline SSC1 & \multirow{2}{*}{15.09 .17} & 0 & 67 & 0 & & \\
\hline SSC1 & & 0 & 69 & 0 & & \\
\hline
\end{tabular}

Table 1. Overview of the Bubble Catcher experiments. Details of the sampled gas volumes, experiment durations, and volumetric flows of the captured gas are shown.

spanning $20 \mathrm{~s}$ were analyzed, with the second pulse lasting $\sim 5 \mathrm{~s}$. Similar to the other pulsing vent at Rostocker Seep, the onset of a bubble pulse at the second vent was accompanied by larger bubbles. $Q$ was $0.29 \mathrm{~mL}_{\text {gas }} \mathrm{s}^{-1}$ and $A$ was $4.9 \mathrm{~cm}^{2} \mathrm{~s}^{-1}$.

A small minor vent at IV Super Seep (SSV1, Fig. 3c) was analyzed based on 7,850 bubble images and found bubbles spanning $400<r<8,000 \mu \mathrm{m}$ with a dominant mode at $r=1,540 \mu \mathrm{m}$ and $Q=0.16 \mathrm{~mL}_{\mathrm{gas}}{ }^{-1}$, and $A=3.0$ $\mathrm{cm}^{2} \mathrm{~s}^{-1}$.

The only major vent (where the bubble size distribution is well described by a power law and results from bubble fragmentation) was from the main area of IV Super Seep (SSV2, Fig. 3d); all other vents were minor (Fig. 3ac). At the IV Super Seep main vent (SSV2), 2,404 bubbles spanning 500-2,600 $\mu$ m radius were analyzed (Fig. 3d). $Q$ was $1.3 \mathrm{~mL}_{\text {gas }} \mathrm{s}^{-1}$ per vent and $A$ was $22.7 \mathrm{~cm}^{2} \mathrm{~s}^{-1}$ per vent. $Q$ varied by a factor of $\sim 3$ on a $\sim 2 \mathrm{~s}$ timescale (Supplementary Fig. S1). The dominant emission mode was $r \sim 1,530 \mu \mathrm{m}$, with a second mode at $r \sim 2,270 \mu \mathrm{m}$.

The $A / Q$ ratios of three of the vents (SSV1, RSV2, SSV2) were similar, $\sim 18 \mathrm{~cm}^{-1}$ (Table 1), which was expected given the similarity in the dominant modes of the vents. Emissions were far less steady at the minor than at the major vent and even ceased for $\sim 1 \mathrm{~s}$ in the $40 \mathrm{~s}$ analyzed video, which also showed clear pulsing. Pulses were associated with larger bubbles. The dominant mode similarity with the major vent indicates that grain size (mid sand fraction at all sampling sites) controlled the emissions and that $Q$ was non-critical ${ }^{43,44}$ for all vents. For non-critical flow, $Q$ increases the number of bubbles but the size remains the same, for critical flow, the bubble 
a

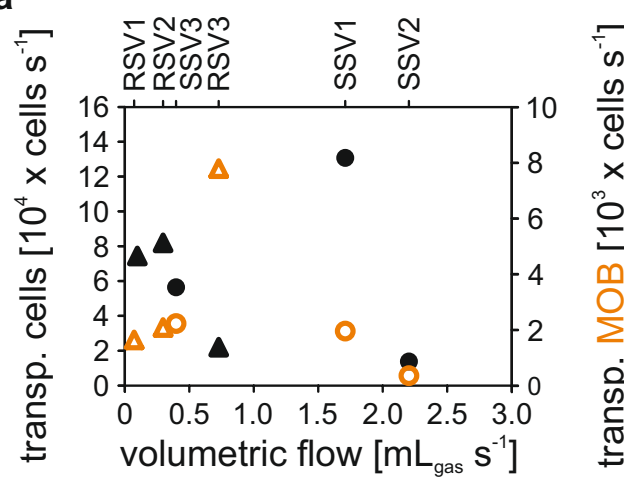

C

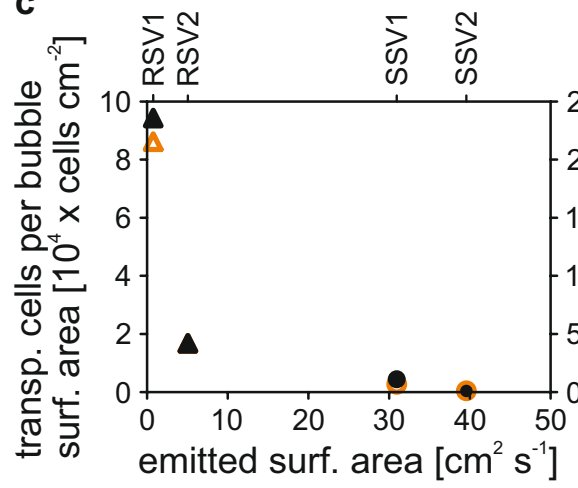

b

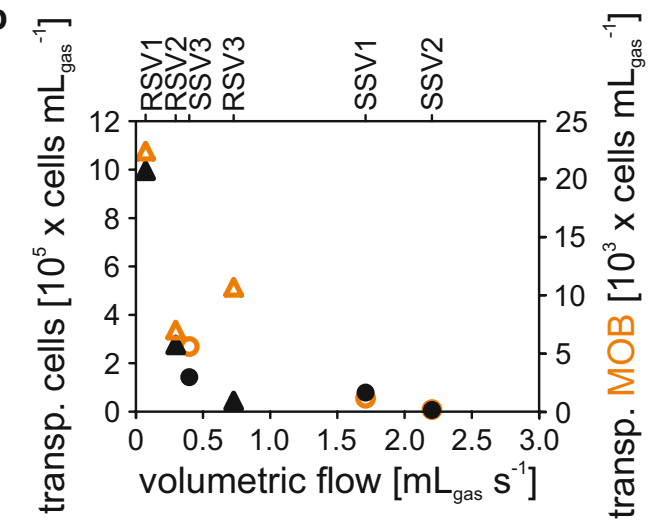

d

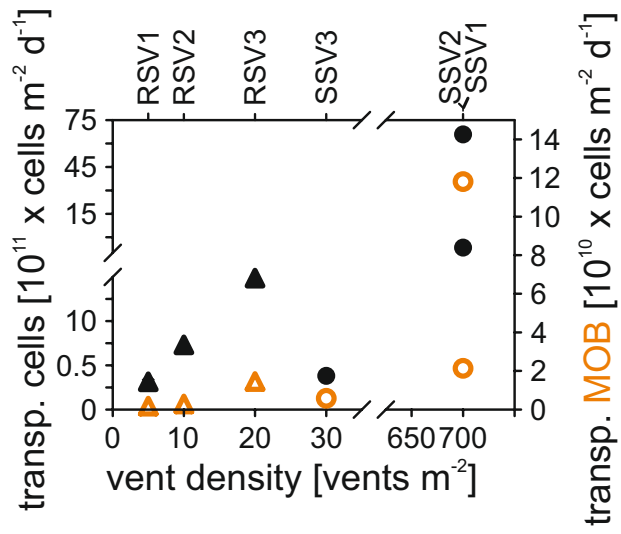

Figure 4. Transported total cells (black) and MOB (orange) at Rostocker Seep (triangle) and IV Super Seep (circles) normalized to (a) time and (b) emitted gas as a function of volumetric flow, (c) bubble surface area as a function of emitted surface area, (d) transported cells per square meter and day versus vent density.

size increases with $Q$. At the minor vent, much less important modes at 580 and $960 \mu \mathrm{m}$, corresponding to $\sim 1 / 3$ and $2 / 3$ of the major mode, were detected.

The BMS data from the IV Super Seep's major vent showed an upwelling flow $\left(V_{u p}\right)$ of $\sim 4 \mathrm{~cm} \mathrm{~s}^{-1}$, which agreed well with the field data-derived relationship between $V_{u p}$ and $Q$ in Leifer $(2010)^{45}$, in which $V_{u p} \sim 4 \mathrm{~cm} \mathrm{~s}^{-1}$ corresponded to $Q \sim 1.2 \mathrm{~mL}_{\mathrm{gas}} \mathrm{s}^{-1}$. For the IV Super Seep minor vent, $V_{u p} \sim 1 \mathrm{~cm} \mathrm{~s}^{-1}$, in good agreement with the $V_{u p}$ of $\sim 1.05 \mathrm{~cm} \mathrm{~s}^{-1}$ as reported previously ${ }^{45}$, corresponds to $Q \sim 1.6 \mathrm{~mL}_{\mathrm{gas}} \mathrm{s}^{-1}$. Interestingly, $V_{x}(r)$ for the main vent followed the shape of $V_{u p}(r)$ for dirty (coated by oil or other surface-active substances) bubbles whereas $V_{x}$ for the minor vent followed $V_{u p}(r)$ for clean bubbles.

For Rostocker Seep, $V_{x}$ suggested clean bubbles. $V_{u p}$ was quite small, roughly $0.25 \mathrm{~cm} \mathrm{~s}^{-1}$ but was challenging to derive for the pulses, as $\mathrm{V}_{\mathrm{x}}$ varied strongly with time, growing nearly an order of magnitude larger in the middle of the pulse. This introduced a $\sim 30 \%$ error into the multiple count correction due to the variation in $\mathrm{V}_{\mathrm{x}}$ and thus in $Q$ and $A$, but not into $A / Q$. As such, there was little change in the $A / Q$ ratio over time, which allowed its application to the $\mathrm{BC}$ volumetric fluxes to derive the $\mathrm{BC}$ area fluxes, even though $\mathrm{BMS}$ and $\mathrm{BC}$ measurements were not concurrent.

Parametrization of the bubble-mediated transport. The bubble transport process was studied using the Bubble Catcher (BC) by sampling gas bubbles escaping (1) a natural vent (BC vent) and (2) an engineered gas outlet without any sediment contact ( $\mathrm{BC}$ engineered). The volumetric flow of the examined vents ranged from $0.07( \pm 8 \%)$ to $0.73( \pm 2 \%) \mathrm{mL}_{\text {gas }} \mathrm{s}^{-1}$ at Rostocker Seep and from $0.04( \pm 2 \%)$ to $2.20( \pm 3 \%) \mathrm{mL}_{\mathrm{gas}} \mathrm{s}^{-1}$ at IV Super Seep (Table 1). The number of transported cells was normalized for time (Fig. 4a), volume of emitted gas (Fig. 4b), transported bubble surface area (Fig. 4c), and $\mathrm{m}^{2}$ seabed seepage area (Fig. 4d) to determine the parameters influencing in the bubble-mediated transport of benthic MOB. MOB were transported in all "BC vent" experiments. The total number of transported cells at the individual vents per time ranged from $1.4 \times 10^{4}$ to $1.3 \times 10^{5}$ cells s$^{-1}$. Transported MOB per vent ranged from $4.1 \times 10^{2}$ to $7.8 \times 10^{3} \mathrm{cells} \mathrm{s}^{-1}$ (Fig. $4 \mathrm{a}$ ). The number of transported MOB and total cells per milliliter of emitted gas (Fig. 4b) decreased with increasing volumetric flow, following an inverse trend that indicated the transport of a 100 times more $\mathrm{MOB}\left(2.27 \times 10^{4} \mathrm{cells} \mathrm{mL}_{\mathrm{gas}}{ }^{-1}\right)$ at the lowest volumetric gas flow $\left(0.07 \mathrm{~mL}_{\text {gas }} \mathrm{s}^{-1}\right)$ than at the maximum investigated flow $\left(2.2 \mathrm{~mL}_{\mathrm{gas}} \mathrm{s}^{-1}, 1.9 \times 10^{2}\right.$ cells $\mathrm{mL}_{\text {gas }}{ }^{-1}$ ). Total cell counts showed a similar trend, with an initial count of $9.96 \times 10^{5}$ cells $\mathrm{mL}_{\text {gas }}{ }^{-1}$ at $0.07 \mathrm{~mL}_{\text {gas }} \mathrm{s}^{-1}$ that declined to $6.2 \times 10^{3}$ cells $\mathrm{mL}_{\text {gas }}{ }^{-1}$ at $2.20 \mathrm{~mL}_{\text {gas }}{ }^{-1}$. Cell transport per unit surface area followed the same inverse trend, ranging from $2.2 \times 10^{3} \mathrm{MOB} \mathrm{cm}{ }^{-2}$ (RSV1) to $1.0 \times 10^{1} \mathrm{MOB} \mathrm{cm}^{-2}$ (SSV2) at a transported bubble surface area $(A)$ of $0.8 \mathrm{~cm}^{2} \mathrm{~s}^{-1}$ and $39.6 \mathrm{~cm}^{2} \mathrm{~s}^{-1}$, respectively (Fig. 4c). The distribution pattern of the total 
a
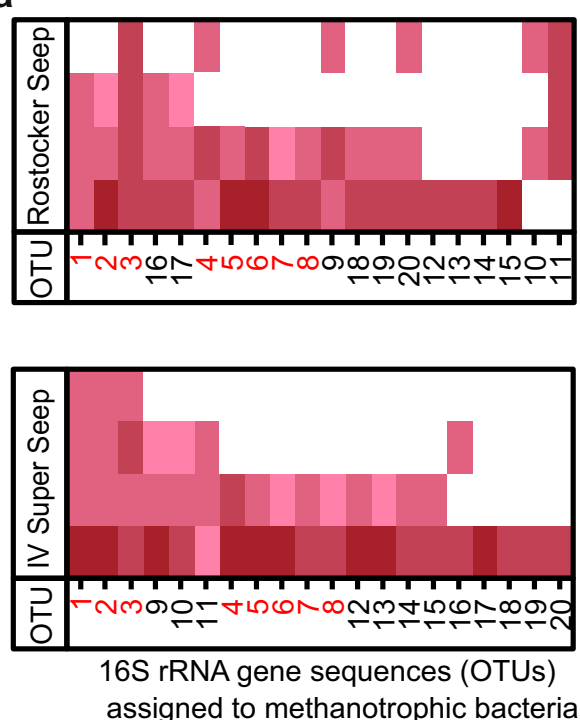

b

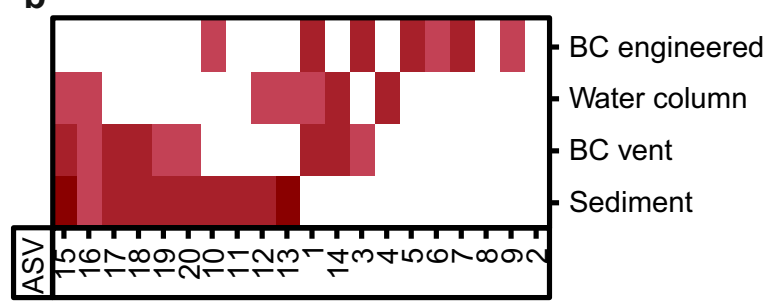

Relative abundance:

$<0.001 \%$

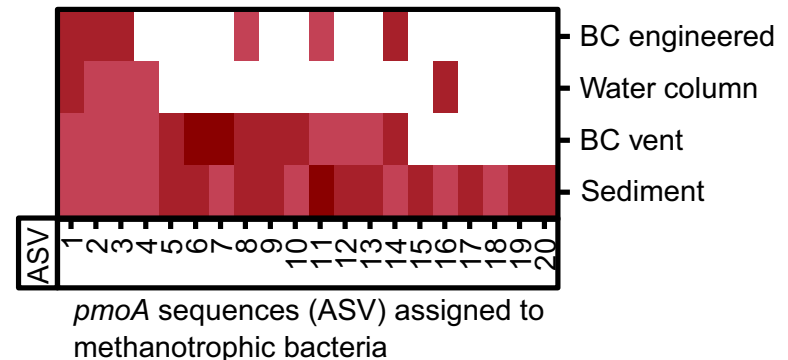

Figure 5. Relative abundance of (a) selected $16 \mathrm{~S}$ rRNA gene sequences (OTUs) assigned to the methanotrophic family Methylomonaceae and (b) selected pmoA sequences (ASVs) in the different sampling groups obtained from the Rostocker Seep and IV Super Seep sites. Note that the OTUs marked in red in (a) had similar distribution patterns at the two seep sites. For taxonomic information on the OTUs and ASVs, see Supplementary Tables S5 and S6, respectively. Data key on figure.

cell counts was essentially identical, with an initial count of $9.4 \times 10^{4} \mathrm{cells} \mathrm{cm}^{-2}$ at $0.8 \mathrm{~cm}^{2} \mathrm{~s}^{-1}$ that decreased to $3.5 \times 10^{2}$ cells cm $\mathrm{cm}^{-2}$ at $39.6 \mathrm{~cm}^{2} \mathrm{~s}^{-1}$. Based on the vents per square meter at the respective study sites, the largest number of MOB was transported by IV Super Seep bubbles, where the vent density was highest, up to 700 vent vents per $\mathrm{m}^{2}\left(1.2 \times 10^{11}\right.$ cells $\mathrm{m}^{-2} \mathrm{~d}^{-1}$; Fig. $\left.4 \mathrm{~d}\right)$, and the lowest number at Rostocker Seep, with only 5 vents per $\mathrm{m}^{2}\left(7.1 \times 10^{8}\right.$ cells $\left.\mathrm{m}^{-2} \mathrm{~d}^{-1}\right)-$ a difference of three orders of magnitude. Note that the observed gas flow spanned over two orders of magnitude (Fig. 4).

DAPI analysis showed that the total cell abundance in the "BC control" experiments was $\sim 3 \times 10^{3} \mathrm{cells}_{\mathrm{s}} \mathrm{mL}^{-1}$, such that mean cell counts in the "BC vent" experiments were $~ 17$ (SS) to 94 (RS) times higher. MOB abundance in the "BC vent" was 24 (SS) to 62 (RS) times higher than in the controls $\left(4 \times 10^{1}\right.$ cells $\mathrm{mL}^{-1}$, Supplementary Table S4). In the "BC engineered" experiments at Rostocker Seep, cell numbers of $8.0 \times 10^{5} \mathrm{cells} \mathrm{mL}_{\mathrm{gas}^{-1}}$ and

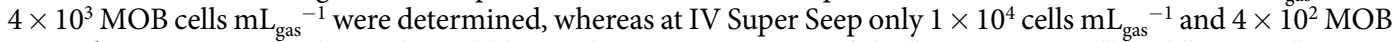
$\mathrm{mL}_{\mathrm{gas}}{ }^{-1}$ were transported into the Bubble Catcher. $\mathrm{A}$ comparison of the "BC engineered" and " $\mathrm{BC}$ vent" experiments indicated that the mean number of total transported cells in the "BC vent" experiments was two (RS) to eight (SS) times higher and four (RS) to six (SS) times higher for MOB.

Identification of transported methanotrophs. To identify transported MOB, the recovered operational taxonomic units (OTUs) and amplicon sequence variants (ASVs) were searched with respect to previously known methanotrophic families. All extracted OTUs were mostly associated with unclassified methanotrophic genera (e.g., unclassified Methylomonaceae, Marine Methylotrophic Group 2, see Supplementary Table S5). OTUs closely related to known MOB have a high probability of being methanotrophic bacteria and hereafter referred to as methanotrophic OTUs. Twenty of 40 detected methanotrophic genera belonging to the family Methylomonaceae were selected for visualization (Fig. 5a). The remaining 20 OTUs were detected only in the sediment. The heat map reveals that some methanotrophic OTUs were detected in all sample groups whereas others had a divergent distribution pattern. Relative abundances based on methanotrophic reads were highest in sediment samples, lower in the "BC vent" sample, and lowest in samples taken from the "BC engineered" experiments and the water column. The highest relative abundance of single methanotrophic OTUs was $0.1-1 \%$. In addition to the family Methylomonaceae, six OTUs assigned to the genus Cycloclasticus (Supplementary Fig. S2) were identified, including four OTUs in the sediment, "BC vent," and water column samples. The maximum relative OTU abundance related to Cycloclasticus was $\sim 1 \%$.

From the particulate methane monooxygenase ( $\mathrm{pmoA}$ ) analysis, $650 \mathrm{ASVs}$ were assigned, of which 42 were found in the Bubble Catcher and in sediments (Fig. 5b). The patterns for pmoA (Fig. 5b) and 16S rRNA genes analyses (Fig. 5a) were similar, with nine ASVs detected in all sample groups and 15 present in the sediment, "BC vent" experiments, and water columns. Of the 36 ASVs belonging to the family Methylomonaceae, 29 could be assigned to Methyloglobulus morosus and three to Methylomicrobium kenyense. One ASV was associated with the family Methylocystaceae, belonging to the order Rhizobiales, and four ASVs were assigned as MOB-like. 


\section{Discussion}

The high gas-venting activity in the Coal Oil Point seep field was reflected by elevated dissolved methane in the sediment and water column (Fig. 2a,d), and agreed with previous studies at similar gas-venting sites ${ }^{7,29,46}$. Water column methane concentrations above the COP seep sites correlated with gas seepage intensity, featuring higher methane concentrations at the more active IV Super Seep site compared to the moderately active Rostocker Seep site.

Total cell numbers in the sediment at both sites were in the range reported in previous studies conducted at $\mathrm{COP}^{7,46}$. MOB were detected at deeper, potentially anoxic sediment depths, a pattern that was previously described by Schmale et al. ${ }^{7}$ at Rostocker Seep, who proposed that the oxygen penetration depth is increased by bubble-driven pore water convection ${ }^{46-48}$. Such convection would allow MOB to settle in deeper, normally anoxic sediment strata. However, MOB cell numbers in our study were one order of magnitude lower than those reported by Schmale et al. ${ }^{7}$. This difference might be explained by the disturbance of the surface sediment by the heavy wind-induced surf in the days before the start of our fieldwork. Kersten et al. ${ }^{49}$ showed that such events have the potential to mix the upper sediment layer and to dislocate surface sediments over distance scales of meters ${ }^{49,50}$. In our study, this surface-sediment refreshing sand transport would have brought MOB-poor sediment into the sampling sites possibly explaining the lower cell numbers. Such an event-driven introduction of medium sand grains of similar sizes to both seep sites would explain the similarity in the bubble size distribution pattern as analyzed at all four vents (Fig. 3).

By including different seep sites, this present study allowed for a first time parameterization of the factors controlling the Bubble Transport Mechanism. These experiments showed that MOB transportation rates (i.e.

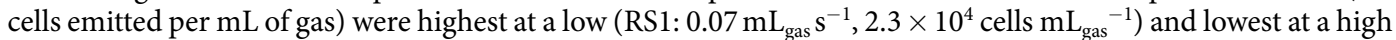

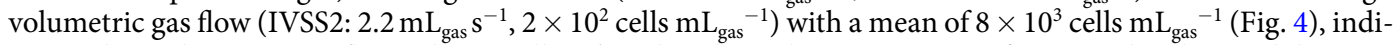
cating that volumetric gas flow substantially affects bentho-pelagic transport efficiency. The observed decrease in transportation rates at higher gas flows implied that microorganisms were removed faster from the sediment than could be compensated by growth and/or supply from the surrounding environment. Another possible explanation for the lower transportation rate could be differences in bubble migration characteristics. At low volumetric gas flows, the sediment migration pathway collapses or partially collapses after each bubble, whereas at higher volumetric flows the conduit remains open for a prolonged period of time ${ }^{51,52}$. In collapsed conduits, particles, pore water, and microorganisms refill the bubble migration pathway. Thus, bubbles slowly migrating through a collapsed conduit have greater potential to interact with the surrounding sediment than do bubbles rising through an open migration path. In addition, it is likely that the continuous gas bubble sparging in an open rise path more rapidly depletes microorganisms. However, a corresponding decrease in cell numbers in the sediment taken above an active vent was not detected in our sediment samples (Fig. 2). This might have resulted from our sampling approach, in which sediment slices were homogenized before subsamples were taken for cell counting. Thus, background sediment cell numbers of $10^{9}-10^{10}$ cells $\mathrm{cm}^{-3}$ could have masked localized depletion.

The overall impact of the Bubble Transport Mechanism on the abundance of MOB in the overlying water column was determined by extrapolating the numbers of cells transported per volumetric gas flow over the number of active vents per square meter of seabed. Our data show that even vents with high volumetric gas flows and accordingly low numbers of transported cells per gas bubble (e.g., IVSSV2, Fig. 4b,c) can have comparatively high cell transportation rates given the high numbers of active vents per seabed area (Fig. 4d). However, as the bubble mediated transport itself is coupled to the volumetric gas flow, we propose that factors influencing this flow, such as hydrostatic pressure ${ }^{53}$ (including waves and tides) ${ }^{41,54}$ and temperature ${ }^{55}$, likely affect the transportation rate of MOBs though these were beyond the scope of the data collected.

We conducted two additional types of Bubble Catcher experiments to allow for the transportation of water-borne microorganisms ("BC engineered") and the introduction of contamination during Bubble Catcher handling ("BC control") and "BC vent" experiments. The "BC control" experiments without gas bubble transport into the sampling cylinder featured low numbers of microorganisms, indicative of minor contamination of our

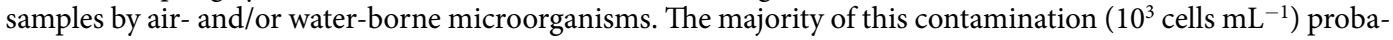
bly resulted from the scuba-diver operations with the Bubble Catcher at the seafloor. Additional microorganisms may have been introduced through sediment that was resuspended by wind and wave action ${ }^{4,5}$. Air-borne contamination during sample handling and filtration were likely low, due to the differences in cell concentration of air $\left(10^{3}-10^{7} \text { cells } \mathrm{m}^{-3}\right)^{56}$ and sample water $\left(10^{10}-10^{11}\right.$ cells $\left.\mathrm{m}^{-3}\right)$.

Although in the "BC vent" experiments, bubbles escaping into the water column were likely loaded with bacteria, fine particles, and surfactants collected from the sediment, the " $\mathrm{BC}$ engineered" experiments were designed to assess the contribution of water column-borne microorganisms to the Bubble Transport Mechanism. Previous studies have shown that particles and microorganisms in the sediment adsorb to the bubble interfaces due to the surface activity of bacterial cells ${ }^{24,57}$. Different to the "BC vent" experiments, bubbles in the engineered bubble experiment were not pre-coated by surfactants prior to their migration through the water column. Thus, engineered bubbles likely provided a greater available surface area for transportation and therefore collected more water-column bacteria before entering the Bubble Catcher $(5 \mathrm{~cm}$ from sediment to Bubble Catcher entrance). If the engineered bubbles were indeed more efficient in sparging microbes from the water column into the Bubble Catcher, then $\mathrm{MOB}$ transport rates, and total cell numbers calculated for the "BC vent" experiments would be underestimated.

The quantitatively observed transport of MOB with catalyzed reporter deposition fluorescence in situ hybridization (CARD-FISH) was supported by genetic analyses. Based on methanotrophic OTUs, some benthic MOB were transported from the sediment into the water column while others remained in the sediment. A bubble-mediated bentho-pelagic transport of methanotrophs was indicated by the detection of methanotrophic OTUs, in the sediment, in the "BC vent", and in the water column samples (IV Super Seep OTUs: 1, 2, 3, 9, 10, 11; Rostocker Seep OTUs: 1, 2, 3, 17, 16). Four of these OTUs were also found in the samples from the "BC 
engineered" experiments (IV Super Seep: 3; Rostocker Seep: 1), which confirmed the bubble-induced stripping of bacteria from the water column into the Bubble Catcher sampling cylinder. This mechanism would have the potential to dislocate microorganisms within the water column, even across boundary layers such as pycnoclines. The detection of 18 methanotrophic OTUs in both sediment and "BC vent" samples (IV Super Seep OTUs 4-8, 12-15; Rostocker Seep OTUs 4-8, 9, 18-20), which were absent in the water column, suggests that some MOB cells transported into the Bubble Catcher either quickly sank back to the seafloor or perished in the pelagic environment. The transport patterns from 8 of 20 methanotrophic OTUs were similar at the two seep sites (red OTU numbers, Fig. 5a), whereas there was no such similarity for the ASV distribution. Microbial transport efficiency may be affected by the specific cell surface activity of microorganisms, which results, for example, from inter-species differences in outer membrane composition and extracellular components ${ }^{58,59}$ but also depends on the growth conditions (e.g., nutrient levels) ${ }^{60}$. Also, the cell position in a biofilm can influence their anchorage on particles and their likelihood of detachment by external forces ${ }^{61}$. In addition, a recent study on the aerosolization of bacteria and viruses at the ocean-atmosphere interface suggested that cell morphology is a critical parameter that influences bubble-induced transport between these two environments ${ }^{62}$.

Our pmoA analysis supported the $16 \mathrm{~S}$ rRNA gene-based transportation pattern. The six ASVs found in the sediment, "BC vent" experiment, and water column provided evidence of the bubble-mediated transport of benthic MOB across these habitats. Among the transported ASVs, 37 were assigned to the family Methylomonaceae, which agreed with the $16 \mathrm{~S}$ rRNA gene results. However, the identified ASVs probably belonged to unknown marine species, because the only assignments that could be made using the reference database was to a species isolated from a freshwater lake (Methyloglobulus morosus), whose growth is reduced already at a very low salinity ${ }^{63}$, as well as to a species isolated from a Kenyan soda lake, which grows optimum is at $\mathrm{pH}>9$ (Methylomicrobium kenyense $)^{64}$. Based on current knowledge, neither species was likely to have existed in the sampled environment.

A previous study by Tavormina et al. ${ }^{65}$ used $p m o A$ sequences from sediment and water column ( $3 \mathrm{~m}$ above sea floor) samples to investigate MOB community structure in two methane vent environments at water depths between 500 and $700 \mathrm{~m}$, at the Eel River Basin and the Santa Monica Basin, respectively. A comparison of the 16 $p m o A$ isolates in sediment and water samples from the two sites showed distinct methanotrophic communities with very little overlap between the two environments. In addition, the $16 \mathrm{~S}$ rRNA gene analysis did not recover methanotrophic lineages. By contrast, we detected 40 OTUs belonging to methanotrophic lineages, of which eight were shared by the seep sediment and overlaying water column. However, using next generation sequencing methods resulted in a higher sequencing depth than achieved with the clone-library-dependent sequencing technique used by Tavormina et al. ${ }^{65}$. The difference in techniques and the respective sensitivities might explain the differences in the observed community overlap. Another possible explanation for the absence of benthic MOB in the water column in the Tavormina et al. ${ }^{65}$ study could have been the sampling depth ( $3 \mathrm{~m}$ above the seafloor). During their travel through the water column, ascending gas bubbles released at greater water depth continuously exchange gases with the surrounding water via their surfaces, resulting in a general decrease in bubble size with increasing distance from the seabed. It is expected that the constant shrinking of the gas bubbles surface during ascending ${ }^{25}$ increases the shear stress on the attached microbial cells leading to a preferential release of MOB at shallower water depth. For the time of our study the elevated shear stress at the bubble surface provoked by wake eddies $^{66}$ support the detachment of microorganisms already near the seabed. Differences in environmental factors, such as oxygen concentration in the water column, seep characteristics, and volumetric gas flows, between the COP seep field and the seep sites investigated by Tavormina et al. ${ }^{65}$ may also explain the lack of MOB in the water column.

Although the 16S rRNA gene analysis indicated an overlap between the methanotrophic communities, no information could be obtained about the metabolic activity of the transported cells. The fact that some of the transported OTUs were found in the water column while others occurred only in the "BC vent" experiments suggests different survival rates of sediment-borne bacteria in the water column. However, Bubble Catcher water samples from the "BC vent" experiments provided direct evidence of methane oxidation in incubations performed over a 3-day runtime directly after Bubble Catcher subsampling. Averaged methane oxidation rates of "BC vent" ( $\left.~ 900 \mathrm{nmol} \mathrm{L}^{-1} \mathrm{~d}^{-1}\right)$ were three orders of magnitude higher than "BC engineered" $(\sim 0.6 \mathrm{nmol} \mathrm{L}-1$ $\left.\mathrm{d}^{-1}\right)$ and five orders of magnitude higher than "BC control $\left(\sim 0.005 \mathrm{nmol} \mathrm{L}^{-1} \mathrm{~d}^{-1}\right)$ rates. Thus, at least some of the transported MOB were active after their dislocation into the water column.

To assess the impact of the Bubble Transport Mechanism in the COP water column on MOB abundance, we performed a rough calculation to derive the transportation time and distance required to achieve the detected water column MOB stock (Fig. 2c). For the calculation, we assumed a constant bubble-mediated MOB input into the overlying water column and survival of the transported organisms. Calculation were performed for two different intensities of sediment-born MOB inputs: (i) maximum input as measured at the IVSS site, and (ii) minimum input as detected at the Rostocker seep site (Fig. 4). According to these assumptions, it takes about (i) 3 hours $(1 \mathrm{~km})$ to (ii) 14 days $(121 \mathrm{~km})$, respectively, of bubble-mediated transport to reach the number of water column MOB cells observed. Even if MOB cell division (about 3 days) ${ }^{37}$ within the methane-enriched plume water would further shorten these transportation times, our assessment shows that a relevant part of the water-column MOB stock was likely transported from gas-releasing seep sites further upstream from the COP seep field. Such a scenario is likely since the shallow waters along the southern Californian coast harbor gas-bubble releasing seep sites for at least over $100 \mathrm{~km}$ upcurrent ${ }^{41,67}$. These seeps will contribute to a high ambient water column MOB concentration while the waters are transported northwards by the coastal current system ${ }^{67-69}$. However, for a solid estimate of the effect of the bubble-transport mechanism on the water column MOB stock in seep regions, an isolated seep area, with low and uniform background MOB concentrations, and a defined current system would be required.

Aside from MOB, our genetic analysis further indicated the transport of OTUs assigned to the genus Cycloclasticus (Supplementary Fig. S2). Members of this genus have been reported to metabolize polycyclic 


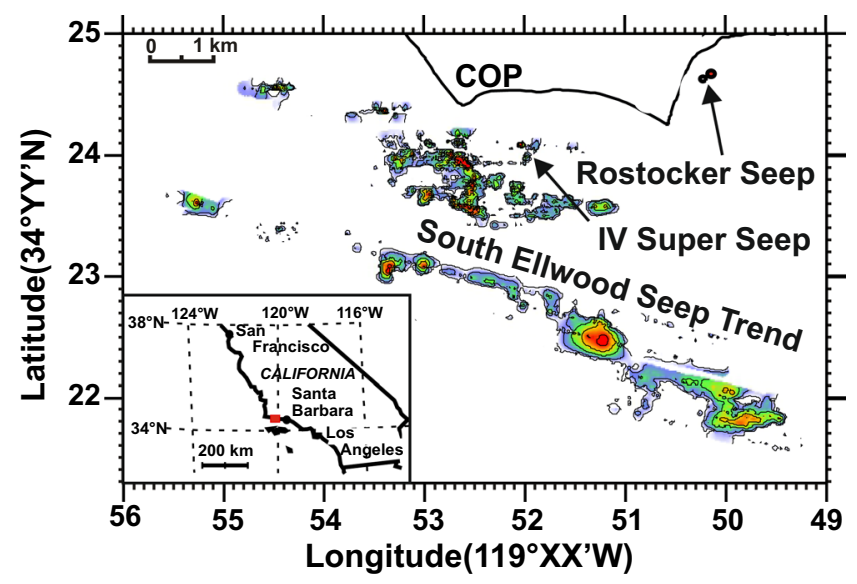

Figure 6. Sonar map of seep bubble intensity in the Coal Oil Point seep field. Adapted from Leifer et al. ${ }^{78}$. Matlab, Mathworks (v. R2008a) was used to create this map.

aromatic hydrocarbons (PAHs) ${ }^{70,71}$ and have been playing a dominant role in the degradation of oil ${ }^{72}$, for example in the Deepwater Horizon oil spill ${ }^{73,74}$. In addition, symbiotic Cycloclasticus associated with mussels and sponges use short-chain alkanes rather than PAHs. However, so far no members of the genus Cycloclasticus were observed to oxidize methane ${ }^{73,75}$. We propose that Cycloclasticus species play a role in the degradation of petroleum compounds in the sediment and water column of $\mathrm{COP}^{76,77}$, with the latter being enhanced by the bubble-mediated transport. Consequently, it is conceivable that this transport mechanism influences other biogeochemical processes in the vicinity of gas seeps, too.

\section{Materials and Methods}

Study site. The Coal Oil Point (COP) seep in southern California, USA, extends from the coastline to 3-4km offshore, with seepage from water depths of a few meters up to $80 \mathrm{~m}$ (Fig. 6) ${ }^{41,78,79}$. COP seeps are primarily or entirely supplied by gas, mostly methane $(>90 \%)$, from the underlying Monterey Formation through faults and fractures in the overlying Sisquoc Formation ${ }^{78}$. Methane originates from thermogenic sources underlying the Santa Barbara Channel, at sub-seafloor depths of 3-4 $\mathrm{km}^{80}$. In a 1995 estimate, seabed emissions of $\sim 1.0-1.5 \times 10^{5}$ $\mathrm{m}^{3} \mathrm{~d}^{-1}$ gas (88\% methane) were reported ${ }^{77}$. Approximately half of this methane dissolves in the water, the other half reaches the atmosphere ${ }^{76}$. A dissolved, submerged methane plume then is transported down-current remaining detectable for $50 \mathrm{~km}^{81}$.

The COP field allows perfect access for divers and equipment to a variety of gas vents that was a prerequisite for our investigations. Field experiments were conducted between 1 August and 15 September 2017 at two scuba-diver-accessible seep sites in the COP seep field (Fig. 6), chosen to span a range of seep intensities. The Rostocker Seep is located in 10-m-deep water. Its seeps have a relatively low volumetric gas flow ${ }^{7}$, a high methane content $(>91 \%)^{82,83}$, and no oil emissions. The Isla Vista Super Seep, located at 16-m-deep water, has an intense, focused seep area surrounded by extensive dispersed small seep vents, and emits gas bubbles with $>95 \%$ methane ${ }^{78,83}$. Previous studies in the COP seep field demonstrated methane oxidation in sediment ${ }^{46}$ and water column $^{82,84}$.

Bubble Catcher experiment and subsampling. The Bubble Catcher (outer dimensions: $35 \mathrm{~cm} / 35 \mathrm{~cm} /$ $90 \mathrm{~cm}$ ) used herein was similar to that in Schmale et al. ${ }^{7}$, but the sampling cylinder (volume $12.7 \mathrm{~L}$ ) was made of glass. A funnel and a stopcock directed and opened/closed the bubble flow, respectively, and a relief pressure valve prevented overpressure during surfacing (Fig. 7). A metal frame stabilized and protected the glass cylinder.

Prior to its deployment, the cylinder was filled with sterile-filtered seawater subsampled for total cells and MOB cell abundances to check for possible contamination. During the experiment, the captured bubbles (4-6L) displaced Bubble Catcher water. Particles and microorganisms associated with the seep bubbles were released into the sterile-filtered water in the sampling cylinder after the bubbles had burst. Experiment durations and collected gas volumes were used to calculate the volumetric gas flow $\left(\mathrm{mL}_{\mathrm{gas}} \mathrm{s}^{-1}\right)$. After gas collection the Bubble Catcher was returned to the boat and the BMS was deployed from a second vessel and positioned at the exact same vents. Push cores were taken last as they are disrupting the sediment. Water column sampling was conducted during the runtime of the Bubble Catcher experiments. Bubble Catcher subsampling occurred within $1 \mathrm{~h}$ after return to shore.

To parameterize the bubble-mediated transport process, gas bubbles were sampled from different gas vents of the Rostocker Seep and IV Super Seep sites. The sampling process is shown schematically in Supplementary Fig. S3. Three experiment types were conducted, details and an overview of the experiments duration and sampled gas volumes are provided in Table 1. For the "BC vent" experiments, divers placed the Bubble Catcher above an active natural gas vent. In the "BC engineered" experiments ("BC blank" in Schmale et al. ${ }^{7}$ ), the Bubble Catcher was placed above an engineered gas bubble source, created by air released from a pressure tank, positioned at least $\sim 1 \mathrm{~m}$ from any gas vent. The bubble stream was adjusted to resemble volumetric flow and bubble size of natural vents in the vicinity. In "BC control" experiments, no bubbles were introduced into the Bubble Catcher, which was positioned as described for the "BC engineered" experiments. During subsampling, residual water in the Bubble 


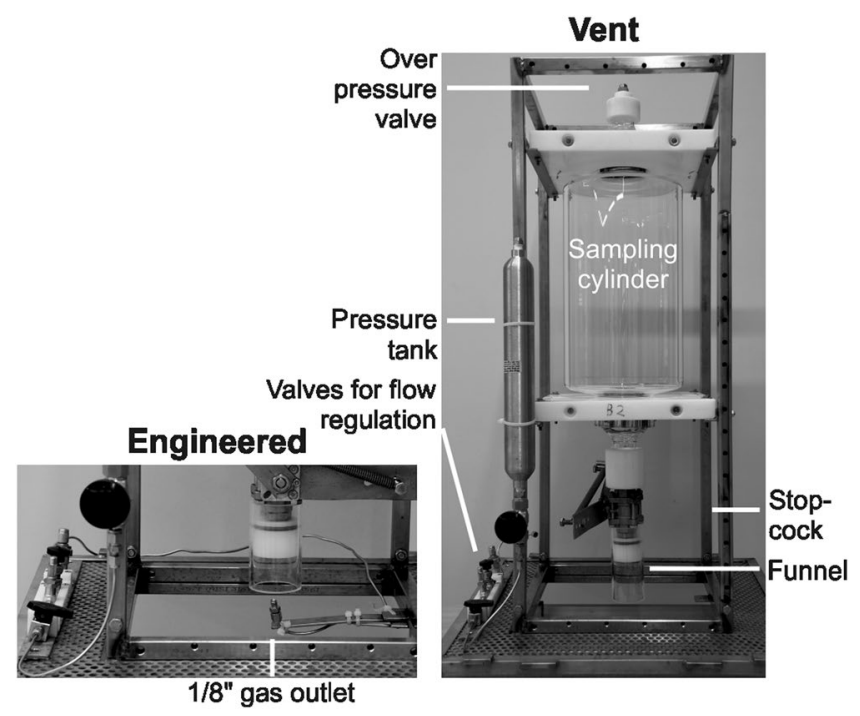

Figure 7. The Bubble Catcher used in the "BC vent" experiments (right) and in the "BC engineered" experiments (left).

Catcher was homogenized using a sterilized mixing rod, inserted through a small opening at the top of the Bubble Catcher, and filled into prepared sampling containers. The water sample was transferred via a sterilized glass funnel that was placed on the bottom of the respective container. Samples for methane oxidation rates determination and methane concentration measurement were subsampled bubble free without sample overflow, due to sample volume limitation. Total sample volume was determined by incremental filling. Methane concentration, MOB abundances, $\mathrm{MOB}$ community, and methane oxidation rates (only determined in the water column and Bubble Catcher) were analyzed from: (i) residual Bubble Catcher water, (ii) the sediment, and (iii) the water column.

Sediment and water column sampling. Sediment samples were collected as push cores (length $30 \mathrm{~cm}$, inner diameter $5 \mathrm{~cm}$ ) to determine sediment methane depth profiles and confirm the presence of MOB that could be transported into the water column.

Consistent with the high vent density at IV Super Seep the cores SSV1 and SSV2 were taken from sites of active venting. Other cores were taken at a distance of $\sim 15 \mathrm{~cm}$ from any active vents. Cores for methane determination were processed on land directly by subsampling sediment plugs horizontally through openings pre-drilled in the core-liner at $1.5 \mathrm{~cm}$ depth increments to a maximum depth of $10.5 \mathrm{~cm}$, using $3 \mathrm{~mL}$ cut-off plastic syringes. Cores for MOB abundance analyses were cooled $\left(4^{\circ} \mathrm{C}\right)$ during transport to the laboratory and kept refrigerated $\left(4^{\circ} \mathrm{C}, 18-42 \mathrm{~h}\right)$ until subsampled in $1.5 \mathrm{~cm}$ increments.

The physical, chemical, and biological parameters of the water column were monitored to characterize sea water in proximity to Rostocker Seep and IV Super Seep. Salinity, temperature, and depth were monitored periodically over the course of a fieldwork day using a handheld sensor (CTD48M, Sea \& Sun Technology GmbH, Germany). Water samples were collected with a $2 \mathrm{~L}$ handheld water sampler (LIMNOS, Finland) at depths of 1, 5, and $9 \mathrm{~m}$ at Rostocker Seep site and 1, 5, 10, and $15 \mathrm{~m}$ at IV Super Seep site.

Methane concentration. To determine the methane concentration in the water column and Bubble Catcher, $125 \mathrm{~mL}$ of sample water was filled bubble-free directly into crimp vials from the Bubble Catcher and handheld water sampler, respectively. All samples were cooled $\left(3 \mathrm{~h}, 4^{\circ} \mathrm{C}\right)$ until processed in the lab. The crimp vials were injected with $10 \mu \mathrm{L}$ of saturated $\mathrm{HgCl}_{2}$ solution $/ \mathrm{mL}$ of sample and stored inverted ${ }^{85}$. The samples were analyzed for methane using the headspace method $^{86}$, by manually injecting $30 \mu \mathrm{L}$ of headspace gas with a gastight syringe (Hamilton $100 \mu \mathrm{L}$ ) into a gas chromatograph (Agilent GC $7890 \mathrm{~B}$, temp. program $45^{\circ} \mathrm{C}$ ). Each sample was analyzed twice. If the mean deviation between the measurements was $>1 \%$, a third measurement was conducted. For calibration, two standard gases were used with (1) $97.7 \mathrm{ppm} \mathrm{CH}_{4}$, injection volume $50 \mu \mathrm{L}$, and (2) $3950 \mathrm{ppm}$ $\mathrm{CH}_{4}$, injection volume $20 \mu \mathrm{L}$, in syn. air (Linde) with an uncertainty of $\pm 2 \%$ by manufacturer. The standards were measured five times with a mean deviation of $<1 \%$ at the beginning and end of each day.

For sediment methane concentrations, $2 \mathrm{~cm}^{3}$ of sediment from each depth was transferred into $10 \mathrm{~mL}$ crimp vials filled with $5 \mathrm{~mL}$ of $2.5 \% \mathrm{NaOH}$. The vials were stored inverted at $4{ }^{\circ} \mathrm{C}$. Methane concentrations were determined by injecting $30 \mu \mathrm{L}$ of headspace gas from each vial as described above.

Methane oxidation rates. Methane oxidation rates were measured in the water column and to ensure the activity of the collected MOB after Bubble Catcher sampling. $100 \mathrm{~mL}$ of sample water was filled bubble-free directly into crimp vials and sealed with non-toxic PTFE-coated chlorobutyl rubber stoppers (Wheaton, USA) ${ }^{87}$. All samples were cooled $\left(4^{\circ} \mathrm{C}\right)$ until further processing in the lab. Methane oxidation rates were determined according to Bussmann et al. ${ }^{88}$ with slight modifications. Thus, $20 \mu \mathrm{L}$ of gaseous ${ }^{3} \mathrm{H}-\mathrm{CH} 4$ tracer (1:3 dilution with $\mathrm{N}_{2}, \sim 50 \mathrm{kBq}$, specific activity $0.37-0.74 \mathrm{TBq} / \mathrm{mmol}$, American Radiolabeled Chemicals, USA) was added to every sample. Radioactivity was measured by liquid scintillation counting (PerkinElmer, TRI-CARB 4910TR, USA). 
Oxidation rates were calculated using the determined rate constant multiplied by the methane concentration. For "BC vent" samples, methane saturation was assumed and calculated after Wiesenburg and colleagues ${ }^{89}$ because $^{\circ}$ methane gas bubbles purged permanently through the sample during the experiment time.

Quantification of MOB. MOB and total cell abundances were analyzed in sediment, water column, and Bubble Catcher samples to quantify the transport of benthic MOB into the water column. For the CARD-FISH analysis, $100 \mathrm{~mL}$ of Bubble Catcher sample was filled into sterile centrifuge tubes $(50 \mathrm{ml})$, for water column samples the volume was adjusted to $20 \mathrm{ml}$, cooled $\left(3 \mathrm{~h}, 4^{\circ} \mathrm{C}\right)$ until further processing in the lab. Sediment samples were processed as described in Schmale et al. ${ }^{7}$, using the ultrasonic probe (Bandelin HD70 Sonopuls, Germany). An aliquot of $3 \mathrm{~mL}$ (dilution 1:3000) was filtered on $0.2 \mu \mathrm{m}$ filters. All sample filters were prepared and analyzed according to Pernthaler et al..$^{90}$. For hybridization, the probes $\mathrm{M}(\gamma) 84$ and $\mathrm{M}(\gamma) 705$, specific for type I MOB, and $\mathrm{M}(\alpha) 450$, specific for type II MOB, were used as described previously ${ }^{7}$, except that they were pre-labeled with horseradish peroxidase. Filters were counterstained with 4',6-diamidino-2-phenylindole (DAPI) to determine total cell counts.

Each Bubble Catcher experiment was corrected for the number of cells inside the Bubble Catcher prior to its deployment. Determined cell numbers in the "BC vent" and "BC engineered" experiments were also corrected for the cell numbers in the "BC control" experiments. The number of cells $\mathrm{mL}^{-1}$ was multiplied by the water volume of the residual sample to determine the number of transported cells per Bubble Catcher and then divided by the volume of captured gas to calculate the transported cells $\mathrm{mL}_{\mathrm{gas}}{ }^{-1}$ (Fig. $4 \mathrm{~b}$ ). These rates were multiplied by the volumetric flow to obtain the number of transported cells $\mathrm{s}^{-1}$ (Fig. 4a). The number of transported cells per bubble surface area (cells cm $\mathrm{cm}^{-2}$ ) was determined from bubble size distributions measured by the BMS (Fig. 4c). The number of transported cells $\mathrm{m}^{-2} \mathrm{~d}^{-1}$ (Fig. $4 \mathrm{~d}$ ) was calculated by multiplying the number of transported cells $\mathrm{s}^{-1}$ by the vent density.

DNA extraction and 16S rRNA gene/pmoA sequencing. For DNA analysis, Bubble Catcher and water column samples were filtered on hydrophilic polycarbonate membrane filters $(0.22 \mu \mathrm{m}, 47 \mathrm{~mm}$, Merck Millipore, Darmstadt, Germany), which were stored at $-80^{\circ} \mathrm{C}$ until analysis. To ensure sufficient biomass, $0.5-1 \mathrm{~L}$ (water column) and 1-2 L (Bubble Catcher) sample water were filtered. For sediment samples, the sediment's upper $1.5 \mathrm{~cm}$ was homogenized and a subsample was transferred to a cryogenic vial that was stored at $-80^{\circ} \mathrm{C}$ until extraction. DNA was extracted from one-quarter of the membrane filter (for water column samples) or $0.25 \mathrm{mg}$ of wet sediment with the DNeasy PowerSoil Pro kit (Qiagen). The V3-V4 region of the 16S rRNA gene was targeted with the primer set 451f-805r (forward: CCTACGGGNGGCWGCAG, reverse: GACTACHVGGGTATCTAATCC) ${ }^{91}$. For $p m o A$, the primer set A189fmod and mb661rmod (forward: GGNGACYGGGAYTTCTGG, reverse: CMGGMGCAACGTCYTTACC), a combination of two established sets ${ }^{65,92}$, was used. LGC Genomics $\mathrm{GmbH}$ (Berlin, Germany) performed library preparation and sequencing on an Illumina MiSeq V3 (600 cycle, $2 \times 300 \mathrm{bp}$, 5 million reads). Sequences were deposited in the European Nucleotide Archive (ENA) under accession number PRJEB34318 (16S rRNA gene) and PRJEB34319 ( $p m o A)$. 16S rRNA gene amplicon sequences were grouped into OTUs based on a similarity $>97 \%$ and classified to the genus level.

$16 \mathrm{~S}$ rRNA gene amplicon read processing and annotation were conducted using Mothur v. 1.39.5 $5^{93}$ (MiSeq SOP: accessed on 02.04.2019). Taxonomic annotation was accomplished using the Silva database (release 132), including the taxonomic changes proposed by Parks et al. ${ }^{94}$. For $p m o A$ sequences, the raw sequences were processed with DADA2 v. 1.12.195, which uses ASV instead of OTUs, and taxonomically annotated according to the pmoA reference database ${ }^{96}$. The phylogenetic analysis was performed with R v. 3.5.197 and phyloseq v. 1.26.0 $0^{98}$.

OTUs (for $16 \mathrm{~S}$ rRNA gene analysis) were selected based on their taxonomic relationship to described MOB. ASVs present in at least two sample groups were selected. OTUs and ASVs present in control samples were removed from the analysis. Samples were grouped regarding their sample origin (sediment, "BC vent", water column, "BC engineered"). The mean relative abundance per group and per OTU/ASV was calculated and visualized with ggplot2 v. 3.1.099.

Bubble size distribution analysis. The bubble measurement system and analysis algorithms are described elsewhere ${ }^{42,45,100-103}$. Video was digitized at $60 \mathrm{fps}$. All bubbles in a sequence were identified and tracked manually due to high particle and detritus concentrations in the samples. Tracking assistance was provided by the algorithms in ImageJ v. $1.52^{102}$. Once a bubble was selected in two sequential frames, the algorithm predictively attempts to select the same bubble in the next frame based on the expected vertical displacement. If the predictive attempt fails, then the bubble was selected manually. The bubble equivalent spherical radius, $r$, is determined from a best-fit ellipse of the bubble outline, both with and without a convex hull. Further analysis was conducted using custom routines in MATLAB v. 2018b (Mathworks, MA). The velocity of tracked bubbles was derived and a polynomial was fit to the vertical velocity (accounting for camera tilt) as a function of $r, V_{x}(r) . V_{x}(r)$ then allowed determination of the observation frequency of bubbles of each size class in the field of view to derive a multiple count correction for the flux (number of bubbles $\mu \mathrm{m}^{-1}$ radius $\mathrm{s}^{-1}$ ), which was calculated as time-resolved. Where $V_{x}(r)$ varied significantly with time, an error is introduced since the algorithm uses a single $V_{x}(r)$ which is calculated from all bubbles measured. This error was estimated at $30 \%$ for pulsing plumes which showed the largest variation in $V_{x}(r, \mathrm{t})$.

Bubble plumes can be characterized as major or minor, where major plumes are described by a power law and are formed by bubble fragmentation, and minor plumes are described by a Gaussian function ${ }^{42}$. For minor plumes, the radius of the peak of the Gaussian function, termed the mode, is determined solely by sediment grain size if the emission flux $(Q)$ is below a critical value ${ }^{44}$. For $Q$ above the critical value, the mode also depends on $Q$. The characteristic mode radius was determined from a least squares linear regression fit of a Gaussian function (or functions if multiple modes) using the MATLAB curve fitting tool. Integration of the emission size 
distribution over $r$ at each time provides the time trend in total bubble volume and surface area as well as the rates of emissions of plume bubbles $Q\left(\mathrm{~mL}_{\mathrm{gas}} \mathrm{s}^{-1}\right)$ and surface area $(A)\left(\mathrm{cm}^{2} \mathrm{~s}^{-1}\right)$.

Contribution of the Bubble Transport Mechanism to the water column MOB stock. The transportation distance $(\Delta x)$ needed to achieve the detected average water column MOB cell concentration $(c)$ was calculated from the current velocity $(v)$, the water depth $(z)$, and the sediment-born MOB flux $(F)$ as shown in Eq. 1.

$$
\Delta x=\frac{c \cdot v \cdot z}{F}
$$

Calculations were performed with the following variables:

\begin{tabular}{|l|l|l|l|l|}
\hline & $\boldsymbol{c}\left(\right.$ cells $\left.^{-3}\right)$ & $\boldsymbol{v}\left(\mathbf{m ~ s}^{-1}\right)$ & $\boldsymbol{z}(\mathbf{m})$ & $\boldsymbol{F}\left(\right.$ cells $\left.^{-2} \mathbf{s}^{-1}\right)$ \\
\hline IVSS & $1 \times 10^{9}$ & $0.1^{69,104}$ & 16 & $1.38 \times 10^{6}$ \\
\hline RS & $1 \times 10^{9}$ & $0.1^{69,104}$ & 10 & 8217 \\
\hline
\end{tabular}

Received: 6 September 2019; Accepted: 5 February 2020;

Published online: 13 March 2020

\section{References}

1. Yamahara, K. M., Layton, B. A., Santoro, A. E. \& Boehm, A. B. Beach Sands along the California Coast Are Diffuse Sources of Fecal Bacteria to Coastal Waters. Environ. Sci. Technol. 41, 4515-4521 (2007).

2. Shibata, T., Solo-Gabriele, H. M., Fleming, L. E. \& Elmir, S. Monitoring marine recreational water quality using multiple microbial indicators in an urban tropical environment. Water Res. 38, 3119-3131 (2004).

3. Russell, T. L., Yamahara, K. M. \& Boehm, A. B. Mobilization and Transport of Naturally Occurring Enterococci in Beach Sands Subject to Transient Infiltration of Seawater. Environ. Sci. Technol. 46, 5988-5996 (2012).

4. Ferguson, D. M., Moore, D. F., Getrich, M. A. \& Zhowandai, M. H. Enumeration and speciation of enterococci found in marine and intertidal sediments and coastal water in southern California. J. Appl. Microbiol. 99, 598-608 (2005).

5. Orvain, F., Hir, P. L. \& Sauriau, P. A model of fluff layer erosion and subsequent bed erosion in the presence of the bioturbator, Hydrobia ulvae. J. Mar. Res. 61, 821-849 (2003).

6. Jamieson, R. C., Joy, D. M., Lee, H., Kostaschuk, R. \& Gordon, R. J. Resuspension of Sediment-Associated Escherichia coli in a Natural Stream. J. Environ. Qual. 34, 581-589 (2005).

7. Schmale, O. et al. Bubble Transport Mechanism: Indications for a gas bubble-mediated inoculation of benthic methanotrophs into the water column. Cont. Shelf Res. 103, 70-78 (2015).

8. Bertagnolli, A. et al. Bacterial diversity in the bottom boundary layer of the inner continental shelf of Oregon, USA. Aquat. Microb. Ecol. 64, 15-25 (2011).

9. Stevens, H., Brinkhoff, T. \& Simon, M. Composition of free-living, aggregate-associated and sediment surface-associated bacterial communities in the German Wadden Sea. Aquat. Microb. Ecol. 38, 15-30 (2005).

10. Ziervogel, K. \& Arnosti, C. Enzyme activities in the Delaware Estuary affected by elevated suspended sediment load. Estuar. Coast. Shelf Sci. 84, 253-258 (2009).

11. Garstecki, T., Wickham, S. A. \& Arndt, H. Effects of Experimental Sediment Resuspension on a Coastal Planktonic Microbial Food Web. Estuar. Coast. Shelf Sci. 55, 751-762 (2002).

12. Shimeta, J., Amos, C. L., Beaulieu, S. E. \& Ashiru, O. M. Sequential resuspension of protists by accelerating tidal flow: Implications for community structure in the benthic boundary layer. Limnol. Oceanogr. 47, 1152-1164 (2002).

13. Guizien, K. et al. Microorganism dynamics during a rising tide: Disentangling effects of resuspension and mixing with offshore waters above an intertidal mudflat. J. Mar. Syst. 129, 178-188 (2014).

14. Forehead, H., Thomson, P. \& Kendrick, G. A. Shifts in composition of microbial communities of subtidal sandy sediments maximise retention of nutrients. FEMS Microbiol. Ecol. 83, 279-298 (2013).

15. Kvenvolden, K. A. \& Rogers, B. W. Gaia’s breath - Global methane exhalations. Mar. Pet. Geol. 22, 579-590 (2005).

16. Weber, T., Wiseman, N. A. \& Kock, A. Global ocean methane emissions dominated by shallow coastal waters. Nat. Commun. 10, $1-10(2019)$.

17. Reeburgh, W. S. Oceanic Methane Biogeochemistry. Chem. Rev. 107, 486-513 (2007).

18. Leifer, I. \& Patro, R. K. The bubble mechanism for methane transport from the shallow sea bed to the surface: A review and sensitivity study. Cont. Shelf Res. 22, 2409-2428 (2002).

19. Naudts, L. et al. Active venting sites on the gas-hydrate-bearing Hikurangi Margin, off New Zealand: Diffusive- versus bubblereleased methane. Mar. Geol. 272, 233-250 (2010).

20. Wan, J. \& Wilson, J. L. Visualization of the role of the gas-water interface on the fate and transport of colloids in porous media. Water Resour. Res. 30, 11-23 (1994).

21. Leifer, I. \& Judd, A. G. Oceanic methane layers: the hydrocarbon seep bubble deposition hypothesis. Terra Nov. 14, 417-424 (2002).

22. Blanchard, D. C. Bubble Scavenging and the Water-to-Air Transfer of Organic Material in the Sea. In Applied Chemistry at Protein Interfaces 360-387 (1975).

23. Leifer, I., de Leeuw, G. \& Cohen, L. H. Secondary bubble production from breaking waves: The bubble burst mechanism. Geophys. Res. Lett. 27, 4077-4080 (2000).

24. Wan, J., Wilson, J. L. \& Kieft, T. L. Influence of the gas-water interface on transport of microorganisms through unsaturated porous media. Appl. Environ. Microbiol. 60, 509-516 (1994).

25. McGinnis, D. F., Greinert, J., Artemov, Y., Beaubien, S. E. \& Wüest, A. Fate of rising methane bubbles in stratified waters: How much methane reaches the atmosphere? J. Geophys. Res. 111, C09007 (2006).

26. Steinle, L. et al. Water column methanotrophy controlled by a rapid oceanographic switch. Nat. Geosci. 8, 378-382 (2015).

27. Schneider von Deimling, J. et al. Quantification of seep-related methane gas emissions at Tommeliten, North Sea. Cont. Shelf Res. 31, 867-878 (2011).

28. Nauw, J., de Haas, H. \& Rehder, G. A review of oceanographic and meteorological controls on the North Sea circulation and hydrodynamics with a view to the fate of North Sea methane from well site 22/4b and other seabed sources. Mar. Pet. Geol. 68, 861-882 (2015).

29. Steinle, L. et al. Linked sediment and water-column methanotrophy at a man-made gas blowout in the North Sea: Implications for methane budgeting in seasonally stratified shallow seas. Limnol. Oceanogr. 61, S367-S386 (2016). 
30. Schmale, O. et al. Aerobic methanotrophy within the pelagic redox-zone of the Gotland Deep (central Baltic Sea). Biogeosciences 9 , 4969-4977 (2012).

31. Valentine, D. L. Emerging Topics in Marine Methane Biogeochemistry. Ann. Rev. Mar. Sci. 3, 147-171 (2011).

32. Saunois, M. et al. The global methane budget 2000-2012. Earth Syst. Sci. Data 8 (2016).

33. Redmond, M. C., Valentine, D. L. \& Sessions, A. L. Identification of Novel Methane-, Ethane-, and Propane-Oxidizing Bacteria at Marine Hydrocarbon Seeps by Stable Isotope Probing. Appl. Environ. Microbiol. 76, 6412-6422 (2010).

34. Steinle, L. et al. Effects of low oxygen concentrations on aerobic methane oxidation in seasonally hypoxic coastal waters. Biogeosciences 14, 1631-1645 (2017).

35. Schubert, C. J. et al. Methanotrophic microbial communities associated with bubble plumes above gas seeps in the Black Sea. Geochemistry, Geophys. Geosystems 7 (2006).

36. Durisch-Kaiser, E., Klauser, L., Wehrli, B. \& Schubert, C. Evidence of Intense Archaeal and Bacterial Methanotrophic Activity in the Black Sea Water Column. Appl. Environ. Microbiol. 71, 8099-8106 (2005).

37. Kessler, J. D. et al. A Persistent Oxygen Anomaly Reveals the Fate of Spilled Methane in the Deep Gulf of Mexico. Science (80). 331, 312-315 (2011)

38. de Angelis, M. A., Lilley, M. D. \& Baross, J. A. Methane oxidation in deep-sea hydrothermal plumes of the endeavour segment of the Juan de Fuca Ridge. Deep Sea Res. Part I Oceanogr. Res. Pap. 40, 1169-1186 (1993).

39. Law, C. S. et al. Geological, hydrodynamic and biogeochemical variability of a New Zealand deep-water methane cold seep during an integrated three-year time-series study. Mar. Geol. 272, 189-208 (2010).

40. Schubert, C. J. et al. Aerobic and anaerobic methanotrophs in the Black Sea water column. Environ. Microbiol. 8, 1844-1856 (2006).

41. Leifer, I. A Synthesis Review of Emissions and Fates for the Coal Oil Point Marine Hydrocarbon Seep Field and California Marine Seepage. Geofluids 2019, 1-48 (2019)

42. Leifer, I. \& Boles, J. Measurement of marine hydrocarbon seep flow through fractured rock and unconsolidated sediment. Mar. Pet. Geol. 22, 551-568 (2005).

43. Vazquez, A., Leifer, I. \& Sánchez, R. M. Consideration of the dynamic forces during bubble growth in a capillary tube. Chem. Eng. Sci. 65, 4046-4054 (2010).

44. Leifer, I. \& Culling, D. Formation of seep bubble plumes in the Coal Oil Point seep field. Geo-Marine Lett. 30, 339-353 (2010).

45. Leifer, I. Characteristics and scaling of bubble plumes from marine hydrocarbon seepage in the Coal Oil Point seep field. J. Geophys. Res. 115, C11014 (2010).

46. Treude, T. \& Ziebis, W. Methane oxidation in permeable sediments at hydrocarbon seeps in the Santa Barbara Channel, California. Biogeosciences 7, 3095-3108 (2010).

47. Haeckel, M., Boudreau, B. P. \& Wallmann, K. Bubble-induced porewater mixing: A 3-D model for deep porewater irrigation. Geochim. Cosmochim. Acta 71, 5135-5154 (2007).

48. Dando, P. R. et al. Hydrothermal studies in the Aegean sea. Phys. Chem. Earth, Part B Hydrol. Ocean. Atmos. 25, 1-8 (2000).

49. Kersten, M., Leipe, T. \& Tauber, F. Storm Disturbance of Sediment Contaminants at a Hot-Spot in the Baltic Sea Assessed by ${ }^{234} \mathrm{Th}$ Radionuclide Tracer Profiles. Environ. Sci. Technol. 39, 984-990 (2005).

50. Williams, J. J. \& Rose, C. P. Measured and predicted rates of sediment transport in storm conditions. Mar. Geol. 179, 121-133 (2001).

51. Boudreau, B. P. et al. Bubble growth and rise in soft sediments. Geology 33, 517 (2005)

52. Algar, C. K., Boudreau, B. P. \& Barry, M. A. Release of multiple bubbles from cohesive sediments. Geophys. Res. Lett. 38, 2-5 (2011).

53. Römer, M., Riedel, M., Scherwath, M., Heesemann, M. \& Spence, G. D. Tidally controlled gas bubble emissions: A comprehensive study using long-term monitoring data from the NEPTUNE cabled observatory offshore Vancouver Island. Geochemistry, Geophys. Geosystems 17, 3797-3814 (2016).

54. Schneider von Deimling, J., Greinert, J., Chapman, N. R., Rabbel, W. \& Linke, P. Acoustic imaging of natural gas seepage in the North Sea: Sensing bubbles controlled by variable currents. Limnol. Oceanogr. Methods 8, 155-171 (2010).

55. Aben, R. C. H. et al. Cross continental increase in methane ebullition under climate change. Nat. Commun. 8, 1682 (2017).

56. Hu, W. et al. Concentration and viability of airborne bacteria over the Kuroshio extension region in the northwestern pacific ocean: Data from three cruises. J. Geophys. Res. Atmos. 122(12), 892-12,905 (2017).

57. Wan, J. \& Wilson, J. L. Colloid transport in unsaturated porous media. Water Resour. Res. 30, 857-864 (1994).

58. Schäfer, A., Hauke, H. \& Zehnder, A. J. B. Bacterial Accumulation at the Air - Water Interface. Environ. Sci. Technol. 32, 3704-3712 (1998).

59. Malhotra, R., Dhawan, B., Garg, B., Shankar, V. \& Nag, T. A comparison of bacterial adhesion and biofilm formation on commonly used orthopaedic metal implant materials: An In vitro study. Indian J. Orthop. 53, 148 (2019).

60. Stenstrom, T. A. Bacterial Hydrophobicity, an Overall Parameter for the Measurement of Adhesion. 55, 142-147 (1989).

61. Jang, H., Rusconi, R. \& Stocker, R. Biofilm disruption by an air bubble reveals heterogeneous age-dependent detachment patterns dictated by initial extracellular matrix distribution. npj Biofilms Microbiomes 3, 1-6 (2017).

62. Michaud, J. M. et al. Taxon-specific aerosolization of bacteria and viruses in an experimental ocean-atmosphere mesocosm. Nat. Commun. 9 (2018)

63. Deutzmann, J. S., Hoppert, M. \& Schink, B. Characterization and phylogeny of a novel methanotroph, Methyloglobulus morosus gen. nov., spec. nov. Syst. Appl. Microbiol. 37, 165-169 (2014).

64. Kalyuzhnaya, M. G. et al. Classification of halo(alkali)philic and halo(alkali)tolerant methanotrophs provisionally assigned to the genera Methylomicrobium and Methylobacter and emended description of the genus. Methylomicrobium. Int. J. Syst. Evol. Microbiol. 58, 591-596 (2008).

65. Tavormina, P. L., Ussler, W. \& Orphan, V. J. Planktonic and Sediment-Associated Aerobic Methanotrophs in Two Seep Systems along the North American Margin. Appl. Environ. Microbiol. 74, 3985-3995 (2008).

66. Clift, R., Grace, J. R. \& Weber, M. E. Bubbles, Drops, and Particles. Academic Press (1978).

67. Heintz, M. B., Mau, S. \& Valentine, D. L. Physical control on methanotrophic potential in waters of the Santa Monica Basin, Southern California. Limnol. Oceanogr. 57, 420-432 (2012).

68. Hickey, B. M. Circulation over the Santa Monica-San Pedro Basin and Shelf. Prog. Oceanogr. 30, 37-115 (1992).

69. Winant, C. D., Dever, E. P. \& Hendershott, M. C. Characteristic patterns of shelf circulation at the boundary between central and southern California. J. Geophys. Res. Ocean. 108, n/a-n/a (2003).

70. Messina, E. et al. Genome sequence of obligate marine polycyclic aromatic hydrocarbons-degrading bacterium Cycloclasticus sp. 78-ME, isolated from petroleum deposits of the sunken tanker Amoco Milford Haven, Mediterranean Sea. Mar. Genomics 25, $11-13(2016)$

71. Wang, W., Wang, L. \& Shao, Z. Polycyclic Aromatic Hydrocarbon (PAH) Degradation Pathways of the Obligate Marine PAH Degrader Cycloclasticus sp. Strain P1. Appl. Environ. Microbiol. 84, 1-15 (2018).

72. Hazen, T. C., Prince, R. C. \& Mahmoudi, N. Marine Oil Biodegradation. Environ. Sci. Technol. 50, 2121-2129 (2016).

73. Kleindienst, S. et al. Diverse, rare microbial taxa responded to the Deepwater Horizon deep-sea hydrocarbon plume. ISME J. 10, 400-415 (2015).

74. Gutierrez, T., Berry, D., Teske, A. \& Aitken, M. Enrichment of Fusobacteria in Sea Surface Oil Slicks from the Deepwater Horizon Oil Spill. Microorganisms 4, 24 (2016). 
75. Lai, Q., Li, W., Wang, B., Yu, Z. \& Shao, Z. Complete genome sequence of the pyrene-degrading bacterium Cycloclasticus sp. strain P1. J. Bacteriol. 194, 6677-6677 (2012).

76. Leifer, I., Clark, J. F. \& Chen, R. F. Modifications of the local environment by natural marine hydrocarbon seeps. Geophys. Res. Lett. 27, 3711-3714 (2000)

77. Hornafius, J. S., Quigley, D. \& Luyendyk, B. P. The world's most spectacular marine hydrocarbon seeps (Coal Oil Point, Santa Barbara Channel, California): Quantification of emissions. J. Geophys. Res. Ocean. 104, 20703-20711 (1999).

78. Leifer, I., Kamerling, M. J., Luyendyk, B. P. \& Wilson, D. S. Geologic control of natural marine hydrocarbon seep emissions, Coal Oil Point seep field, California. Geo-Marine Lett. 30, 331-338 (2010).

79. Fischer, J. P. Oil and tar seeps, Santa Barbara basin, California. in California Offshore Gas, Oil and Tar Seeps 1-62 (California State Lands Commission, 1978).

80. Olson, D. J. Surface and Subsurface Geology of the Santa Barbara-Goleta Metropolitan Area, Santa Barbara County, California. Masters Thesis (1982).

81. Mau, S. et al. Dissolved methane distributions and air-sea flux in the plume of a massive seep field, Coal Oil Point, California. Geophys. Res. Lett. 34, L22603 (2007).

82. Kinnaman, F. S. et al. Gas flux and carbonate occurrence at a shallow seep of thermogenic natural gas. Geo-Marine Lett. 30, 355-365 (2010)

83. Mau, S., Heintz, M. B., Kinnaman, F. S. \& Valentine, D. L. Compositional variability and air-sea flux of ethane and propane in the plume of a large, marine seep field near Coal Oil Point. CA. Geo-Marine Lett. 30, 367-378 (2010).

84. Mau, S., Heintz, M. B. \& Valentine, D. L. Quantification of $\mathrm{CH}_{4}$ loss and transport in dissolved plumes of the Santa Barbara Channel, California. Cont. Shelf Res. 32, 110-120 (2012).

85. Wilson, S. T. et al. An intercomparison of oceanic methane and nitrous oxide measurements. Biogeosciences 15, 5891-5907 (2018).

86. Magen, C. et al. A simple headspace equilibration method for measuring dissolved methane. Limnol. Oceanogr. Methods 12, 637-650 (2014).

87. Niemann, H. et al. Toxic effects of lab-grade butyl rubber stoppers on aerobic methane oxidation. Limnol. Oceanogr. Methods 13 , 40-52 (2015).

88. Bussmann, I., Matousu, A., Osudar, R. \& Mau, S. Assessment of the radio ${ }^{3} \mathrm{H}-\mathrm{CH}_{4}$ tracer technique to measure aerobic methane oxidation in the water column. Limnol. Oceanogr. Methods 13, 312-327 (2015).

89. Wiesenburg, D. A. \& Guinasso, N. L. Equilibrium Solubilities of Methane, Carbon Monoxide, and Hydrogen in Water and Sea Water. J. Chem. Eng. Data 24, 356-360 (1979).

90. Pernthaler, A., Pernthaler, J. \& Amann, R. Fluorescence In Situ Hybridization and Catalyzed Reporter Deposition for the Identification of Marine Bacteria. Appl. Environ. Microbiol. 68, 3094-3101 (2002).

91. Herlemann, D. P. R. et al. Transitions in bacterial communities along the $2000 \mathrm{~km}$ salinity gradient of the Baltic Sea. ISME J. 5, 1571-1579 (2011).

92. Costello, A. M. \& Lidstrom, M. E. Molecular Characterization of Functional and Phylogenetic Genes from Natural Populations of Methanotrophs in Lake Sediments. 65, 5066-5074 (1999).

93. Kozich, J. J., Westcott, S. L., Baxter, N. T., Highlander, S. K. \& Schloss, P. D. Development of a Dual-Index Sequencing Strategy and Curation Pipeline for Analyzing Amplicon Sequence Data on the MiSeq Illumina Sequencing Platform. Appl. Environ. Microbiol. 79, 5112-5120 (2013)

94. Parks, D. H. et al. A standardized bacterial taxonomy based on genome phylogeny substantially revises the tree of life. Nat. Biotechnol. 36, 996-1004 (2018).

95. Callahan, B. J. et al. DADA2: High-resolution sample inference from Illumina amplicon data. Nat. Methods 13, 581-583 (2016).

96. Yang, S., Wen, X. \& Liebner, S. pmoA gene reference database (fasta-formatted sequences and taxonomy). GFZ Data Serv., https:// doi.org/10.5880/GFZ.5.3.2016.001 (2016).

97. R Core Team. R: A language and environment for statistical computing. (2018).

98. McMurdie, P. J. \& Holmes, S. phyloseq: An R Package for Reproducible Interactive Analysis and Graphics of Microbiome Census Data. PLoS One 8, e61217 (2013).

99. Wickham, H. ggplot2: elegant graphics for data analysis. (Springer-Verlag New York, 2009).

100. Leifer, I., Jeuthe, H., Gjøsund, S. H. \& Johansen, V. Engineered and Natural Marine Seep, Bubble-Driven Buoyancy Flows. J. Phys. Oceanogr. 39, 3071-3090 (2009).

101. Leifer, I. \& Tang, D. The acoustic signature of marine seep bubbles. J. Acoust. Soc. Am. 121, EL35-EL40 (2007).

102. Schneider, C. A., Rasband, W. S. \& Eliceiri, K. W. NIH Image to ImageJ: 25 years of image analysis. Nat. Methods 9, 671-5 (2012).

103. Leifer, I., de Leeuw, G. \& Cohen, L. H. Optical Measurement of Bubbles: System Design and Application. J. Atmos. Ocean. Technol. 20, 1317-1332 (2003)

104. Clark, J. F., Washburn, L., Hornafius, J. S. \& Luyendyk, B. P. Dissolved hydrocarbon flux from natural marine seeps to the southern California Bight. J. Geophys. Res. Ocean. 105, 11509-11522 (2000).

\section{Acknowledgements}

We greatly thank the University of California, Santa Barbara (UCSB) for its support during the field work, especially Uta Passow's lab and Julia Sweet. We thank the University of California, Los Angeles (UCLA) for its organization and support during field work and the subsequent analysis. We further thank A. Frahm, E. Hessel, S. Krause, J. Liu, J. Müller, C. Orsini, and C. Pierre for support during field work and scuba dives. R.J. and J.W. personally acknowledge the use of de.NBI cloud and the support of the High Performance and Cloud Computing Group at the Zentrum für Datenverarbeitung of the University of Tübingen and the Federal Ministry of Education and Research (BMBF) through grant no 031 A535A. This work was funded by the German Science Foundation (DFG) through the projects SCHM 2530/7-1 and SCHU 1416/1-4.

\section{Author contributions}

O.S., T.T., H.S.-V., and S.F.A.J. conceived and designed the experiments. S.F.A.J., O.S., T.T., and I.L. conducted fieldwork and performed the experiments. S.F.A.J. (figures 1, 2, 4, 6, 7, S3), I.L. (figures 3, 6, S1), R.J. and J.W. (figures 5, S2) main data interpretation was performed by S.F.A.J. in cooperation with the co-authors. S.F.A.J. wrote the main manuscript text with input from all co-authors. All authors read and approved the final version of the manuscript.

\section{Competing interests}

The authors declare no competing interests. 


\section{Additional information}

Supplementary information is available for this paper at https://doi.org/10.1038/s41598-020-61446-9.

Correspondence and requests for materials should be addressed to S.F.A.J. or O.S.

Reprints and permissions information is available at www.nature.com/reprints.

Publisher's note Springer Nature remains neutral with regard to jurisdictional claims in published maps and institutional affiliations.

(c) (i) Open Access This article is licensed under a Creative Commons Attribution 4.0 International License, which permits use, sharing, adaptation, distribution and reproduction in any medium or format, as long as you give appropriate credit to the original author(s) and the source, provide a link to the Creative Commons license, and indicate if changes were made. The images or other third party material in this article are included in the article's Creative Commons license, unless indicated otherwise in a credit line to the material. If material is not included in the article's Creative Commons license and your intended use is not permitted by statutory regulation or exceeds the permitted use, you will need to obtain permission directly from the copyright holder. To view a copy of this license, visit http://creativecommons.org/licenses/by/4.0/.

(C) The Author(s) 2020 